\title{
Article \\ The Development of Indigofera spp. as a Source of Natural Dyes to Increase Community Incomes on Timor Island, Indonesia
}

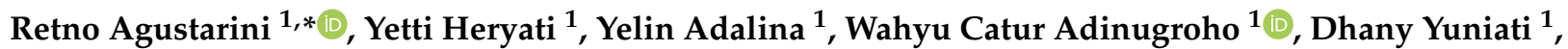 \\ Rizki Ary Fambayun ${ }^{1,2}{ }^{\circ}$, Gerhard Eli Sabastian ${ }^{2}$, Asep Hidayat ${ }^{1}{ }^{(0}$, Hesti Lestari Tata ${ }^{1}(0)$ William Ingram ${ }^{3}(0)$ \\ and Aulia Perdana ${ }^{2}$
}

check for updates

Citation: Agustarini, Retno, Yetti Heryati, Yelin Adalina, Wahyu Catur Adinugroho, Dhany Yuniati, Rizki Ary Fambayun, Gerhard Eli Sabastian, Asep Hidayat, Hesti Lestari Tata, William Ingram, and et al.. 2022. The Development of Indigofera spp. as a Source of Natural Dyes to Increase Community Incomes on Timor Island, Indonesia. Economies 10: 49. https://doi.org/ 10.3390/economies10020049

Academic Editors: Monika Roman, Michał Roman and Ralf Fendel

Received: 18 December 2021 Accepted: 10 February 2022 Published: 15 February 2022

Publisher's Note: MDPI stays neutral with regard to jurisdictional claims in published maps and institutional affiliations.

Copyright: (c) 2022 by the authors Licensee MDPI, Basel, Switzerland. This article is an open access article distributed under the terms and conditions of the Creative Commons Attribution (CC BY) license (https:// creativecommons.org/licenses/by/ $4.0 /)$.
1 Center for Standardization of Sustainable Forest Management Instruments, Ministry of Environment and Forestry, Jalan Raya Gunung Batu No. 5, Bogor 16118, Indonesia; heryatiyetti@gmail.com (Y.H.); yelinadalina@yahoo.com (Y.A.); wahyuk2001@yahoo.com (W.C.A.); dhanyyuniati@yahoo.co.id (D.Y.); R.Fambayun@cgiar.org (R.A.F.); ashephidayat12@gmail.com (A.H.); hl.tata@gmail.com (H.L.T.)

2 World Agroforestry Centre (ICRAF), Bogor 16001, Indonesia; G.Manurung@cgiar.org (G.E.S.); A.Perdana@cgiar.org (A.P.)

3 Threads of Life, Jalan Kajeng 24 Ubud, Bali 80571, Indonesia; william@threadsoflife.com

* Correspondence: retno.agustarini@gmail.com; Tel.: +62-811-848-4080

\begin{abstract}
A strategy that has the potential to contribute to the achievement of the targets established under SDG 8 ("Decent Work and Economic Growth") involves the development of sustainable tourism to create productive job and livelihood opportunities and to promote local culture and products. In the province of East Nusa Tenggara (NTT), Indonesia, ikat weaving is an integral part of the cultural heritage of the region, with ikat characterized by unique design motives and the use of natural dyes. Unfortunately, in some areas, the use of natural dyes is diminishing as a result of competition with synthetic dyes and the limited availability of raw materials, particularly for the production of blue dye. The development of Indigofera spp. to produce natural, plant-based blue dye has significant potential to contribute to community incomes and employment. This study outlines a strategy for developing the use of Indigofera spp. as a natural dye and describes its potential for contributing to community incomes, especially on Timor Island, NTT. The study shows that weavers currently use indigo plants that grow naturally in gardens and yards. Although the community has a tradition of using these plants, informed by local wisdom, to develop the cultivation and processing of this plant through the application of the appropriate techniques, including innovative approaches to producing indigo paste, could enable the development of Indigofera spp. cultivation on a larger scale. The study shows that the availability of suitable land is high ( \pm 370 thousand ha) with $80 \%$ of the suitable land being categorized as critical. The study proposes a development based on the analysis of strengths, weaknesses, opportunities, and threats to assess the manner in which these opportunities could be leveraged with the support and participation of local communities and other stakeholders by leveraging the culture and wisdom of the community regarding the use of Indigofera spp.
\end{abstract}

Keywords: Indigofera spp. cultivation; indigo paste production; economic contribution; land suitability; development strategy

\section{Introduction}

The province of East Nusa Tenggara (hereinafter referred to as NTT) has been in the top three poorest provinces in Indonesia (Beneditus Dalupe 2020; Wiryanta 2007). The livelihoods of the people of NTT still depend on natural resources, $48,7 \%$ obtained from agriculture, forestry, and fisheries, while 34\% from the service sector. Likewise, on Timor Island, $40.35 \%$ of the people depend on natural resources for their livelihoods in agriculture, forestry, and fisheries (BPS Provinsi NTT 2021). However, NTT has creative economic potential through the culture-based tourism industry. With the increasing importance of 
achieving the Sustainable Development Goals (SDGs) in various situations, tourism can play an important role in achieving goal number 8 of the 17 SDGs (UNWTO and UNDP 2017; Dahles et al. 2020; Scheyvens and Hughes 2019; Westoby et al. 2021).

Tourism, if implemented sustainably, seeks to balance the three pillars, namely economy, society, and the environment (Saarinen 2018; Sharpley 2020; Westoby et al. 2021). Although not always evenly distributed, tourism can increase income for many local people (Nugroho and Numata 2020). The expansion of cultural tourism towards intangible cultural heritage and contemporary culture has created more attention for the increased integration between tourism and the creative economy (Richards 2018).

The famous cultural product of the NTT community is ikat weaving (Amaral and Ikat 2019; Bessie et al. 2021; Dioh 2020; Luik et al. 2021; Wangge 2021), which is a hereditary culture from the ancestors of the NTT people with diverse geometric patterns (Windiyarti 2006; Hartono 2010; Tas'au 2016). The making of $i k a t$ is considered as a woman's activity; a tradition passed down from mothers to their daughters (Sulaiman and Anita 2020). Ikat is family property that has a high value as a symbol of social, religious, cultural, and economic status (Elvida 2015; Wangge 2021).

Ikat reflects the identity of the different ethnic groups in NTT, with each group having a different style (Susilawati 2010), such as representations of animals (Sumba Island), leaves (Rote Island), silk and embroidery weaving (Timor Island), and warp ikat weaving (Alor Islands) (Salma et al. 2018; Sulayman et al. 2017), also colors that differ widely from those found elsewhere in the archipelago (Dioh 2020) due to the use of natural dyes in its production (Ledoh et al. 2021; Murniati and Takandjandji 2015; Nomleni et al. 2019; Sabuna and Nomleni 2020).

Colored dyes are produced from colored plants (flowers, fruit, seeds, leaves, wood, bark, roots, and other parts), animals (insects that produce red and purple colors), and minerals (metals, metal salts, and oxides, red ocher) (Elsahida et al. 2019). Indigofera tinctoria L. is one of the plants used as a black and blue dye for yarn for making ikat by the community of NTT (Setiawan and Suwarningdyah 2014).

Indigofera species comprise mainly herbs, perennial or annual, shrubs or small-sized trees, distributed in forests, savannas, and disturbed areas (Marquiafável et al. 2009; Gerometta et al. 2020). The lifespan of Indigofera tinctoria L. as a dye producer is 2-3 years (Kurniawan 2020; Ariyanti and Asbur 2018), whereas if it only functions as a land cover it is 1.5-2 years (Kurniawan 2020).

The genus Indigofera, the third-largest in the family Fabaceae, consists of almost 800 species (Prabhu and Bhute 2015; Schrire 2013). However, tropical and subtropical zones are areas in the world where indigo natural plant dyes are widely found (Su et al. 2008; Prabhu and Bhute 2015). The distribution of this species is in Africa and Madagascar, the Sino-Himalayan region, Australia, and Central and South America (Schrire 2013), and a small portion can be found in temperate areas of East Asia (Ponmari et al. 2014).

Several species in the genus Indigofera are known to produce economically valuable indigo dye (Schrire 2013), such as I. tinctoria L. and I. suffruticosa (Marquiafável et al. 2009). This species is also an important prairie legume (Schrire 2013), with many benefits, such as an ornamental plant, soil cover, shade plant, green humus cover, and erosion control (Marquiafável et al. 2009). They are also used for their medicinal properties (Prakash et al. 2007; Renukadevi and Sultana 2011; Santos et al. 2015; Vieira et al. 2007).

Indigo has been used as a natural textile dye since before synthetic dyes were invented. Indigo extraction from Indigofera plants (I. tinctoria L.) started in India, Egypt, and China and then spread to other tropical countries, including Indonesia, while indigo in sThuringia (Europe) came from the woad plant (Isatis tinctoria L.). Indigo extracted from I. tinctoria L. has a better level of color quality than indigo extracted from Isatis tinctoria L., so the European textile industry began to import indigo from India and Indonesia (Głowacki et al. 2012). The development of natural dyes fluctuated with the fame of Indigofera in Indonesia, which was recorded in 1918-1925. The highest export value occurred in 1921, reaching 69,777 kg dry weight (Heyne 1987). 
Natural indigo dye is slowly being replaced by synthetic indigo, and in 1913, the indigo dye used for textile purposes was derived from synthetic indigo (Séquin-Prey 1981; Głowacki et al. 2012). At present, an increasingly large proportion of weavers use synthetic blue dyes, as these dyes are relatively low cost, durable, and readily available, thus resulting in increased efficiency in the manufacturing process (Haji 2010; Indraningsih and Darsih 2013). The use of natural dyes is generally considered less practical, given that the quality of the product is uneven and that the dyes cannot be stored for long periods of time (Samadara 2018). Along with increasing public awareness of the dangers posed by using synthetic dyes, people are returning to using natural dyes that are more environmentally friendly (Angelini et al. 1997; Muzzazinah 2019).

In Indonesia, indigo paste production fluctuates from year to year. Thus far, domestic needs of indigo paste have not been optimally met because there is no industry specifically producing it. Furthermore, the production of indigo paste has only been supplied by household-scale producers in which the raw materials rely on wild or uncultivated plants (Kurniawan 2020).

While 18 species of Indigofera spp. are found throughout Indonesia, only six species can be used to produce natural dyes (Muzzazinah 2016). Several of these species, including I. suffruticosa Mill. and I. tinctoria L., are distributed across the Island of Timor in NTT (Agustarini et al. 2021). The morphology of Indigofera, which grows in the NTT region with its dry area, produces different colors than the same type that grows in Java and Madura (Muzzazinah et al. 2018).

The climate and land of NTT are dry, and most land is not very fertile. The grassland is mainly suitable for animal husbandry and dryland farming (Kwong and Ronnås 2011). This contributes to low economic growth and a limited role in adding gross value (Saragih 2007). The agricultural activities in NTT need to be more market-focused agribusiness. Based on the market potency of indigo as natural dyes, I. tinctoria L. and I. suffruticosa as agricultural commodities could be developed to support cultural tourism.

This paper shows the result of a series of activities conducted on Timor Island on (i) the evaluation of the use of natural dyes on Timor Island; (ii) the identification of best practice cultivation techniques for Indigofera spp.; (iii) socializing the leaf-processing technologies that enable the production of indigo paste for use as dyes; (iv) land suitability analysis for the cultivation of Indigofera spp.; and (v) economic analysis to determine the viability of the cultivation and utilization of Indigofera spp. as a raw material for the production of natural dye. It is hoped that this study will enable the identification of optimal strategies for the development of Indigofera spp. to produce natural dyes on a wide scale and thereby facilitate the achievement of targets established under SDG 8.

\section{Methodology}

\subsection{Research Locations}

The research was conducted in an area of Timor Island, Indonesia, that has a long community tradition of weaving, as shown in Figure 1. Timor is the largest island in NTT ( $>30 \%$ of NTT area), covering an area of \pm 2.9 million ha, with this divided into Indonesian territory $( \pm 50 \%)$ and the independent nation of Timor Leste $( \pm 50 \%)$. The research focused only on the part of the island that is Indonesian territory. Geographically, it is located at coordinates $8^{\circ} 19^{\prime} 17.9^{\prime \prime} \mathrm{S}-10^{\circ} 22^{\prime} 12.9^{\prime \prime} \mathrm{S}$ and $123^{\circ} 27^{\prime} 24.0^{\prime \prime} \mathrm{E}-127^{\circ} 18^{\prime} 06.2^{\prime \prime} \mathrm{E}$. The research was conducted over the period from March 2019 to August 2021.

Timor Island lies at an altitude of 14-1480 m above sea level, with a land slope of about $16 \%$. The soil predominantly consists of inceptisol, which is formed from limestone (sedimentary rock). The air temperature on Timor Island ranges from 24.4 to $33.0^{\circ} \mathrm{C}$, with air humidity levels ranging from 77\% to 79\% (BPS Provinsi NTT 2021). According to the SchmidtFerguson climate classification system, Timor Island can be categorized either as moderately dry or dry (E and F), with relatively long dry seasons (Andrianyta and Hermawan 2017). On average, 6 to 7 months of the year can be categorized as wet, while 5 to 6 months can 
be categorized as dry. The number of rainy days ranges from 91 to 92 , with the amount of annual rainfall ranging from 1211 to $1242 \mathrm{~mm}_{\text {year }}^{-1}$ (BPS Provinsi NTT 2021).
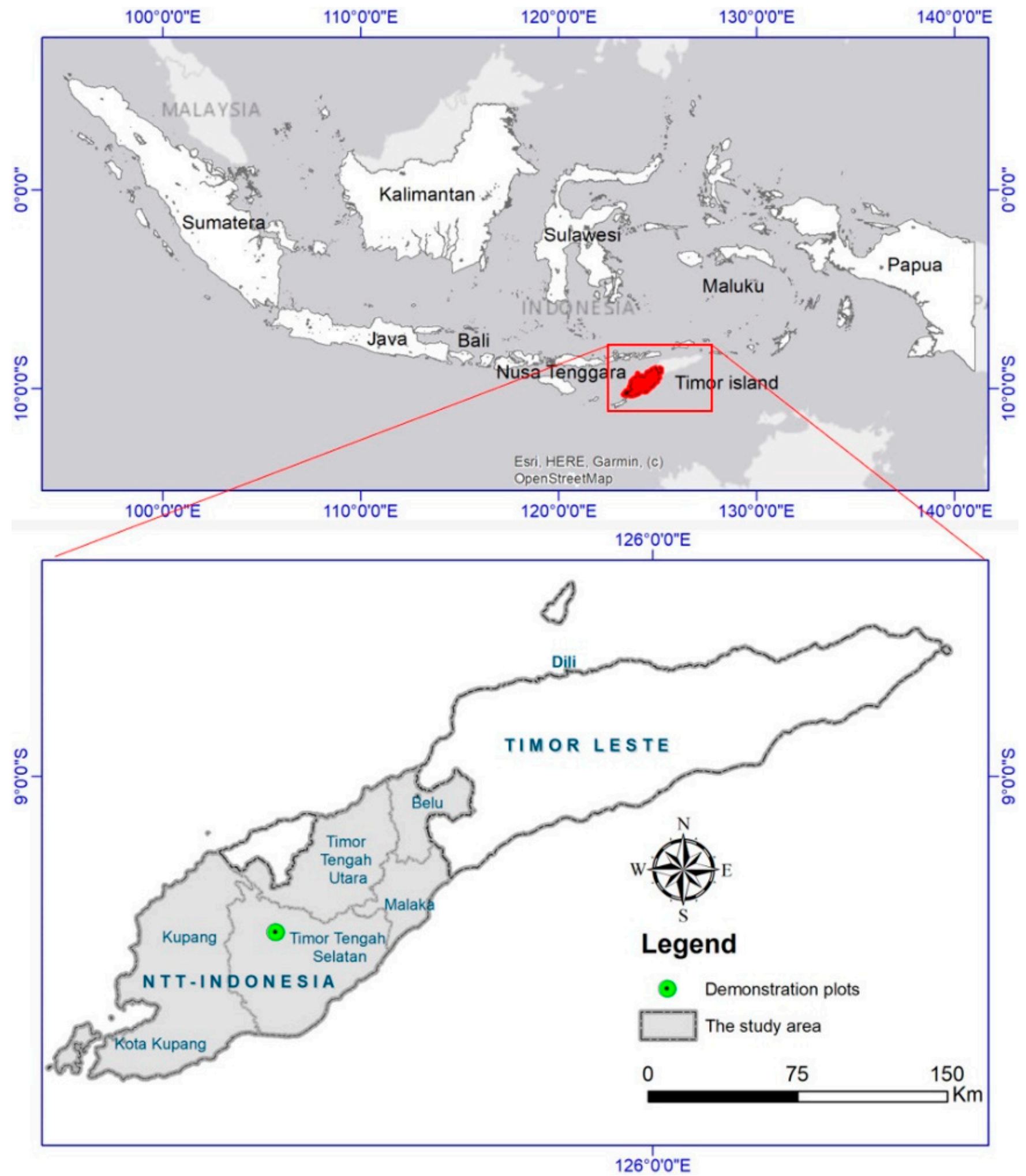

Figure 1. Research location. 


\subsection{Research Methods}

\subsubsection{Evaluation of Community Cultivation and Utilization of Indigofera spp.}

An evaluation of community cultivation of Indigofera spp. was conducted first through a survey of the literature, followed by interviews with members of weaving communities and other stakeholders. Community data was collected in three villages in the district of Timor Tengah Selatan (TTS) on Timor Island, these being Fatumnasi, Bosen, and Oel Ekam. The informants were selected using purposive sampling techniques (Rai and Thapa 2015) according to the research objectives. In-depth interviews were conducted on 3 farmer groups, each consisting of 25 people. The purpose of gauging their knowledge regarding Indigofera spp. and other dyes used, their history of using Indigofera spp., the manner in which they produced and utilized natural dyes, the extent to which they had received training or other support from related institutions, and the degree to which they were interested in cultivating Indigofera spp. to make indigo paste. These interviews were conducted on July 2019.

\subsubsection{Techniques for the Cultivation of Indigofera spp.}

After the evaluation, the patterns of the community utilization of Indigofera spp. were compared with the techniques for its cultivation. The cultivation techniques were examined by observing demonstration plots established by farmer groups in the village of Bosen (North Mollo subdistrict, TTS). The plots were located on a relatively flat area, at an altitude of $600-900 \mathrm{~m}$ asl, with a slope of 3-8\%. With regards to climatic conditions, the demonstration plots received an average annual rainfall of $1000-1500 \mathrm{~mm}$, with an average temperature of $\pm 21-24{ }^{\circ} \mathrm{C}$, and a maximum temperature of $\pm 27-30{ }^{\circ} \mathrm{C}$. The experimental cultivation techniques conducted on these demonstration plots included three main stages, these being: (i) germination, (ii) seeding, and (iii) planting.

(i) Germination: The germination technique applied for the cultivation of I. tinctoria L. involved an experiment that utilized a Completely Randomized Design with two different types of treatment, involving seed scarification and planting media, respectively. The seed scarification treatments involved soaking the seeds in cold water for $24 \mathrm{~h}$; soaking them in pure coconut water $(100 \%)$ for $30 \mathrm{~min}$; or without scarification treatment (control). In terms of planting media, three different treatments were applied, with the seeds sown in a planting medium consisting of: soil; sand; and a mixture of sandy soil (1:1). Thus, the experiment involved nine treatment combinations, with each treatment combination being repeated three times and with each replication consisting of 50 seeds, so the total number of seeds used for all the treatment combinations was 1350 seeds. The parameter observed was the percentage of seeds that germinated.

(ii) Seedling: The experiment was conducted in I. tinctoria L. nurseries using a Divided Plot Design, with shade level treatment as the main plot and nursery media as a subplot. Three different shade levels were investigated $(0 \%, 50 \%$, and $70 \%)$, with four different types of media, these being soil; soil mixed media + cocopeat (1:1); soil mixed media + rice husk charcoal (1:2); and mixed media soil + cocopeat + rice husk charcoal (1:2:2). At each shade level, the different media treatments were repeated six times, with 15 seedlings in each case, with the total number of units at 90 seedlings. The parameters measured were: seedling height and diameter; number of stalks; number of leaves; survival rate; dry weight; Top:Root (TR) ratio; and Seed Quality Index (SQI).

(iii) Planting: The I. suffruticosa Mill. were planted on an area with a slope gradient of about $15 \%$. The field experiment was conducted using a split-plot design, with spacing as the main plot and with the application of manure as the subplot. The main plot consisted of three different spacings between plants, these being $50 \times 50 \mathrm{~cm}$; $75 \times 75 \mathrm{~cm}$; and $100 \times 100 \mathrm{~cm}$. In the subplot involving the application of manure, three different levels were applied: no fertilizer (control), 100, 150, and $200 \mathrm{~g}$ per tree. Each fertilization treatment was repeated three times, with 16 seedlings in each case. 
The parameters that were observed included the survival rate, plant height, and the diameter and number of branches.

\subsubsection{Techniques for Processing Indigofera Leaves to Produce Indigo Paste}

The processing of Indigofera leaves to produce indigo paste begins with harvesting the leaves. Harvesting takes place $4-5$ months after planting when the tree is producing mature brown fruits and bluish green leaves. The best time to conduct the harvesting process, which commences with pruning the leaves at the lower section of the plant $(10-15 \mathrm{~cm}$ from the bottom), is in the morning or late afternoon. An evaluation was also conducted to compare the community's utilization of Indigofera with the application of leaf processing to produce indigo paste.

The processing of Indigofera leaves to produce natural dyes takes place in three stages, these being: the fermentation process; the oxidation or stirring process; and the indigo paste precipitation process. The fermentation process involves soaking the fresh leaves of the Indigofera plant in water, with the soaking time depending on the treatment. The oxidation process involves stirring and aerating the water in which the leaves of Indigofera were soaked, with the addition of some slaked lime $\left(\mathrm{Ca}(\mathrm{OH})_{2}\right)$, by gradually drawing the solution into the air to facilitate the oxidation process, at which point the color of the foam solution turns blue. The indigo paste precipitation process involves storing the indigo solution at room temperature for $24 \mathrm{~h}$ so that the indigo paste settles. Thus, the processing of Indigofera leaves involves the production of a paste by soaking the leaves and adding slaked lime.

\subsubsection{Potential Cultivation Area of Indigofera spp. on the Island of Timor Island, Indonesia}

An assessment of the suitability and availability of land for cultivation of Indigofera spp. was conducted through an analysis facilitated by the geographic information system (GIS), with the analysis utilizing an Analytical Hierarchy Process (AHP) facilitated by Opensource sofware QGIS Desktop version 3.14 and Superdecision version 2.10, free educational software by The Creative Decisions Foundation(Pittsburgh, PA, US). The weight of the criteria was determined on the basis of the AHP, with this weight then being applied to a weighted overlay in the GIS model. This multi-criteria method has been widely used to assess the suitability of land for the production of agricultural commodities (Kumar and Jhariya 2015; Mighty 2015; Widiatmaka 2016).

The land suitability criteria that were applied was consistent with the criteria developed by Indonesia's Ministry of Agriculture in 2011, according to the biophysical characteristics of the demonstration plots. Three different land suitability parameters were applied, these being parameters related to: soil (Texture, $\mathrm{pH}, \mathrm{CEC}, \mathrm{C}-\mathrm{org}$ ); topography (slope class and elevation class); and climate parameters (rainfall, average temperature, and maximum temperature). Data related to the soil parameter were based on the Digital Soil Map of The World (Food and Agriculture Organization of the United Nations 2003), with data related to elevation and slope processed on the basis of SRTM imagery with $90 \mathrm{~m}$ spatial resolution: http:/ /srtm.csi.cgiar.org/ (accessed on 28 September 2021); data related to climate were based on world climate data: https:/ / www.worldclim.org/ (accessed on 28 September 2021); and data related to administrative boundaries were based on Global administrative area: https://gadm.org/ (accessed on 28 September 2021). Data related to land cover, critical land, and land function status were based on the MoEF-Indonesia map product. Land function status related to the status of the land is in forest land/forest state or outside (Other Use Area (Areal Penggunaan Lain, APL)). The Indonesian Ministry of Environment and Forestry (MoEF) applies Consensus-Based Forest Land-Use Planning (Tata Guna Hutan Kesepakatan; TGHK) to establish the forest estate and designate its use. The TGHK mapping program classified forest land (kawasan hutan) by functions: (1) protection forest; (2) conservation forest; (3) limited production forest; (4) production forest for commercial logging; and (5) conversion forest for conversion of degraded production forest to agriculture or other uses. The area outside the forest land is then referred to as APL, 
where this area is intended for cultivation activities, settlements, and other activities; they are public lands that are not designated as Forest Area (Brockhaus et al. 2012). Critical land referred to in this paper refers to a map of critical land created by MoEF, Indonesia. Critical land is the land inside and outside forest areas that have been degraded, resulting in the loss or reduction of ecological function to the specified or expected limit. Its determination is based on the criteria of land cover, slope, hazard level of erosion, productivity, and management (Ministry of Environment and Forestry 2013; Ministry of Environment and Forestry 2018). This is shown in Figure S1 (Steps for Indigofera Land Suitability—Land Availability Analysis).

\subsubsection{Economic Analysis of Indigofera Development}

Indigofera is cultivated through intercropping systems. To determine the added value derived from Indigofera in terms of contributions to community incomes, the analysis only takes into account the economic value of the Indigofera. The economic analysis included a feasibility analysis for the exploitation of indigo paste, a sensitivity analysis, and the calculation of the economic and social potential to be derived from the development of Indigofera spp.

Feasibility Analysis

The scope of the financial feasibility analysis for the commercial production of indigo paste covers all processes, from the cultivation of Indigofera leaves to the treatment of these leaves to produce indigo paste. In this analysis, the cost assessment covers only the operational costs, both fixed costs and variable costs, without any investment costs. Paste-making activities are carried out on a household scale so that it does not require infrastructure facilities that are categorized as investment costs, such as building houses or making soaking tubs.

The wages in the cost assessment is based on the local community wage standard, IDR 65,000 per labor day. This daily wages rate does not differ between woman and man, and type of work. The nature of Indigofera development on Timor Island is a home industry, and the labor was unpaid as they are family members. Wage value is used for analysis purposes only.

Income assessment is carried out by measuring the productivity of Indigofera per ha, then processed into a paste by calculating the yield based on research results of (Agustarini et al. 2021). The analysis of the price of the final product was based on an investigation of the selling price for indigo paste ins the marketplace (Shopee n.d.).

A number of different criteria are commonly used to assess business feasibility, including the following: Net Present Value (NPV), Internal Rate of Return (IRR), Net Benefit Cost Ratio (Net B/C Ratio), and Pay Back Period (PBP) (Nurmalina et al. 2018).

- $\quad$ Net Present Value (NPV)

$$
\mathrm{NPV}=\sum_{\mathrm{t}=0}^{\mathrm{n}} \frac{\mathrm{Bt}-\mathrm{Ct}}{(1+\mathrm{i})^{\mathrm{t}}}
$$

Notes:

NPV = Net Present Value (IDR)

$\mathrm{Bt}$ and $\mathrm{Ct}$ are the benefits and cost, $\mathrm{t}$ is the year in a series ranging from 1 to $\mathrm{n}$, and $\mathrm{i}$ is the discount rate.

- Internal Rate of Return (IRR)

$$
\mathrm{IRR}=\mathrm{i}_{1}+\frac{\mathrm{NPV}_{1}}{\mathrm{NPV}_{1}-\mathrm{NPV}_{2}} \times\left(\mathrm{i}_{1}-\mathrm{i}_{2}\right)
$$

Notes:

IRR = Internal Rate of Return 
$\mathrm{i}_{1}=$ interest rate that results in a positive NPV

$\mathrm{i}_{2}=$ interest rate that results in a negative NPV

$\mathrm{NPV}_{1}=$ positive NPV

$\mathrm{NPV}_{2}=$ negative $\mathrm{NPV}$

- $\quad$ Net Benefit Cost Ratio (Net B/C Ratio)

$$
\operatorname{Net} \frac{B}{C}=\frac{\sum_{t=1}^{n} \frac{B t-C t}{(1+i)^{t}}}{\sum_{t=1}^{n} \frac{B t-C t}{(1+i)^{t}}}, \frac{B t-C t>0}{B t-C t<0 s}
$$

Notes:

Net $B / C=$ Net Benefit Cost Ratio

$\mathrm{Bt}$ and $\mathrm{Ct}$ are the benefits and cost, $\mathrm{t}$ is the year in a series ranging from 1 to $\mathrm{n}$, and $\mathrm{i}$ is the discount rate.

Pay Back Period refers to the period or time (years) that it takes for the investment to yield a positive return, indicated when the NPV value becomes positive. A business may be deemed financially feasible if NPV $>1, \mathrm{BCR}>1$, and the IRR analytic interest rate and PBP are in the business cycle (Tiwa 2016).

\section{Sensitivity Analysis}

A risk model sensitivity analysis can be used to identify the most significant risk factors and to assist in developing priorities for risk mitigation (Frey and Patil 2002). According to (Kumar and Parikh 2001), climatic conditions greatly impact agricultural yields. Climatic anomalies, including those associated with La Nina and El Nino, can affect agricultural productivity. This is one of the factors that need to be considered in conducting a sensitivity analysis. Production costs and changes in the level of productivity of Indigofera spp. are parameters that are determined by prevailing conditions.

The Potential Economic and Social Value of the Development of Indigofera

Economic value is determined on the basis of the net profit value per hectare multiplied by the size of the area deemed to be most suitable (S1) for Indigofera cultivation, with three development target scenarios: $100 \%$ planted area (scenario 1); $50 \%$ planted area (scenario 2 ); and $25 \%$ planted area (scenario 3). Social value is determined on the basis of the rate of labor absorption associated with the development of Indigofera spp.

potential income $=$ net profit value $\times$ land deemed suitable for the cultivation of Indigofera spp.

2.2.6. Development Strategy for the Sustainable Utilization of Indigofera to Produce Natural Dye

Analysis of the strategy for the development of Indigofera was conducted through the application of a SWOT-AHP analysis to the descriptive data. This method has previously been used to formulate agricultural and manufacturing product development strategies for a number of commodities (Ali et al. 2021; Santos et al. 2019; Görener et al. 2012; Kazemi et al. 2018).

The analysis is conducted through the systematic identification of both internal factors, including strengths and weaknesses, and external factors, including opportunities and threats. The SWOT analysis is conducted in a number of stages, including: compiling the Internal Strategic Factors Analysis Summary (IFAS) and External Strategic Factors Analysis Summary (EFAS); analyzing the Internal Factor Evaluation (IFE) Matrix and External Factor Evaluation (EFE) Matrix; and analyzing the Strategy Matrix. Factor weights were determined on the basis of pairwise comparisons between factors using the Analytical Hierarchy Process (AHP). AHP is a mathematical method for multi-criteria decision making developed by (Saaty 2008). 


\section{Results and Discussion}

\subsection{Evaluation of the Cultivation and Utilization of Indigofera spp.}

Plant materials used for the production of colored dyes, especially I. tinctoria L. and Morinda citrifolia L., are collected from nature directly, either by the artisans themselves or by professional collectors (Setiawan and Suwarningdyah 2014). The collection of these plants is informed by different bodies of local wisdom. In Atambua, weavers believe that there is a strong spiritual dimension to the relationship between humans and nature so that they only collect enough plant materials to meet the needs of the producing household income (Siombo 2019). In general, weavers use naturally-growing Indigofera spp. grown in their gardens without any intensive cultivations to meet the production needs of the dye's raw materials (Seran and Hana 2018; Agustarini et al. 2021; Murniati and Takandjandji 2015).

Based on information from weavers in the research location, there are two species of Indigofera spp. in the region, these being I. suffruticosa Mill. and I. tinctoria L. (Agustarini et al. 2021). They explained that the species of Indigofera used produces a particular type of fruit (I. suffruticosa Mill.), as this type is more commonly found in gardens than I. tinctoria L. Users of Indigofera as a natural dye on Timor Island are weavers who are still on a household scale, so they only rely on plants that exist in nature. However, if in the future the industry becomes more developed to support cultural tourism, it is necessary to use cultivation.

The results of interviews with respondents indicate that the community is more familiar with Indigofera for use to produce black dye rather than blue, a finding supported by two other studies (Ledoh et al. 2021; Nomleni et al. 2019). The black color is obtained by mixing clay with Indigofera spp. and applying it to the thread. In this area, a synthetic dye is used for blue. Regarding the composition of the raw materials, they produce the dyes based on their needs and their available equipment. Usually, natural dyes are applied directly to the yarn after they are produced, without any attempts to store them.

The people of Timor Island, NTT, rely mainly on farming or animal husbandry for their livelihood. However, ikat weaving is another livelihood that is no less important. The activity of making ikat has been integrated with the daily activities of the community, especially the women (Buni et al. 2021). In the past, weaving was an activity for leisure time. Nowadays, along with the development of cultural tourism, ikat weaving has became a profitable source of income (Samadara 2018).

Women are more dominant in the activity of making ikat, which can be seen from the composition of weaver respondents, with a composition of $65 \%$ of women and $35 \%$ of men (Table 1). This is supported by the myth that developed in the community, especially in terms of processing Indigofera as a paste. There is a strict taboo forbidding men from being directly involved in producing dye from Indigofera, with a belief that those who violate that taboo will be cursed with infertility (personal communication with Marthen Tualaka, member of Farmer Group in Bosen Village, North Mollo, TTS District on 28 March 2019). Therefore, women dominate the process of manufacturing natural dyes from Indigofera, whereas men are more involved in the cultivation of Indigofera.

Table 1. Respondent information in three (3) research locations.

\begin{tabular}{cccc}
\hline \multirow{2}{*}{ Farmers Group } & Location & \multicolumn{2}{c}{ Gender Proportion of Group Members (\%) } \\
\cline { 3 - 4 } & & Woman & Man \\
\hline Eno Saenman & Fatumnasi & 68.4 & 31.6 \\
Pahlawan & Bosen & 47.1 & 52.9 \\
Paloilmonit & Oel Ekam & 75.0 & 25.0 \\
& & 65.5 & 34.5 \\
\hline
\end{tabular}

The main job of the head of the family is generally as a farmer whose sources of income are very small and also depend on the seasons. In general, the role of the women economically adds to the family's income. However, based on the study of (Buni et al. 2021) 
in Sumba shows that the contribution of women's income to the weaving business and animal rearing is household income is very large, equal to $88 \%$.

Training on the use of Indigofera as a natural blue dye is still rarely done. Thread of Life, a social enterprise that promotes the community-scale production of textiles using traditional materials and techniques as a means of achieving poverty alleviation, has made efforts to introduce the use of Indigofera in producing natural blue dye. In 2016, the organization conducted training programs and other forms of assistance to enable local communities to produce indigo paste from Indigofera with this training. It is expected that there will be an uptake in the use of Indigofera to produce good-quality and highly durable blue dye. Thread of Life could also play a role in facilitating access to markets for the indigo paste and the $i k a t$ that is produced by the community using natural dyes.

The community has responded to these initiatives positively, being open to receiving information and guidance and expressing enthusiasm for cultivating Indigofera spp. and the manufacturing of indigo paste. However, ongoing training and assistance will be needed to enable the community to produce indigo paste that meets market requirements. It is expected that these investments in community capacity building will produce positive impacts and benefits for all stakeholders involved in the cultivation and utilization of Indigofera spp. and for communities more generally.

\subsection{Techniques for the Cultivation of Indigofera spp.}

The system used to cultivate Indigofera spp. was similar to one applied in the Philippines (Mann and Garrity 1994). Indigofera spp. is never cultivated in monoculture systems but is always intercropped with other food-producing and/or commercial crops, including maize, green beans, and tobacco. It has been suggested that the cultivation of Indigofera spp. in multi-crop systems would reduce the need for chemical fertilizers (Garrity et al. 1994). Given that Indigofera spp. is a type of legume, intercropping with this plant could play a positive role in the nitrogen fixation process (Nezomba et al. 2008).

These techniques for the cultivation of Indigofera spp. could be adjusted to meet the needs of members of local communities on Timor Island on the basis of considerations related to the availability of land and applied where intercropping systems are in place for the cultivation of seasonal crops (maize), with the spacing between the plants adjusted in accordance with the conditions required for this system. In general, farmers on Timor Island plant maize with a distance between plants of $75 \times 75 \mathrm{~cm}$, although on dry land, the optimal spacing for maize is $100 \times 50 \mathrm{~cm}$ (Arifin and Tafakresnanto 2019). For the cultivation of Indigofera spp., distances between plants of $100 \times 100 \mathrm{~cm}$ are applied, intercropped with maize (with a spacing of $100 \times 50 \mathrm{~cm}$ ) (Figure 2).

The techniques applied by the community for the cultivation of Indigofera spp. cultivation technique involved a number of stages, from germination to seeding and planting in the field. At each of these stages, the results of the research were applied, with the following identified as the best practice techniques for cultivation:

- Germination. Indigofera seeds are characterized by external dormancy, as is the case with other types of legumes. Thus, they need to be subjected to a process of scarification to overcome this dormancy, with scarification achieved through immersion (Luna et al. 2009). The results of the research demonstrate that the combination of scarification and sowing media had no significant effect on the germination of I. tinctoria $\mathrm{L}$. The treatment that had the greatest impact on germination was the sowing media. The three treatments that have the greatest impact on the germination of the I. tinctoria L. were without scarification (control), soaking in cold water for $24 \mathrm{~h}$, and soaking in pure coconut water $(100 \%)$ for $30 \mathrm{~min}$. These treatments resulted in the highest germination rates in sand media, at $73.33 \%, 77.33 \%$, and $88.00 \%$, respectively (Table S1). By contrast, seeds sown on soil media and on a mixture of soil and sand produced a germination rate below $50 \%$. This indicates that sand is a suitable medium for sowing I. tinctoria L. seeds. Even though the sand medium is poor in nutrients, according to (Wiryanta 2007), sand contains a number of minerals essential for the 
plants' growth. In addition, the porosity of the sand media enables imbibition and adequate aeration, enabling the seeds to germinate rapidly.

- $\quad$ Seedling. Based on experience on Timor Island, planting Indigofera directly from seeds in the field without going through a nursery will cause delays in leaf harvesting. Planting using seedlings will harvest at the age of 4 months while using direct seedings when the plant is one year old. The successful growth of the plants is heavily dependent on the quality of the seeds, with the quality of the seeds being determined by the media used in the nursery. Therefore, mixed media with a sufficient level of nutrients and porosity results in the production of high-quality seeds. In addition, according to (Fredrick et al. 2020; Onyekwelu et al. 2012; Veloso et al. 2017), light intensity is another environmental factor that affects the survival and growth rates of seedlings with each plant species requiring a different light intensity for growth. Research shows that $I$. tinctoria $\mathrm{L}$. seedlings planted in a mixed media consisting of soil, cocopeat, and rice husk charcoal (1:2:2) and placed in an unshaded location (0\%) had the highest TR ratio and SQI, namely 5.53 and 0.0030, respectively (Table S2).

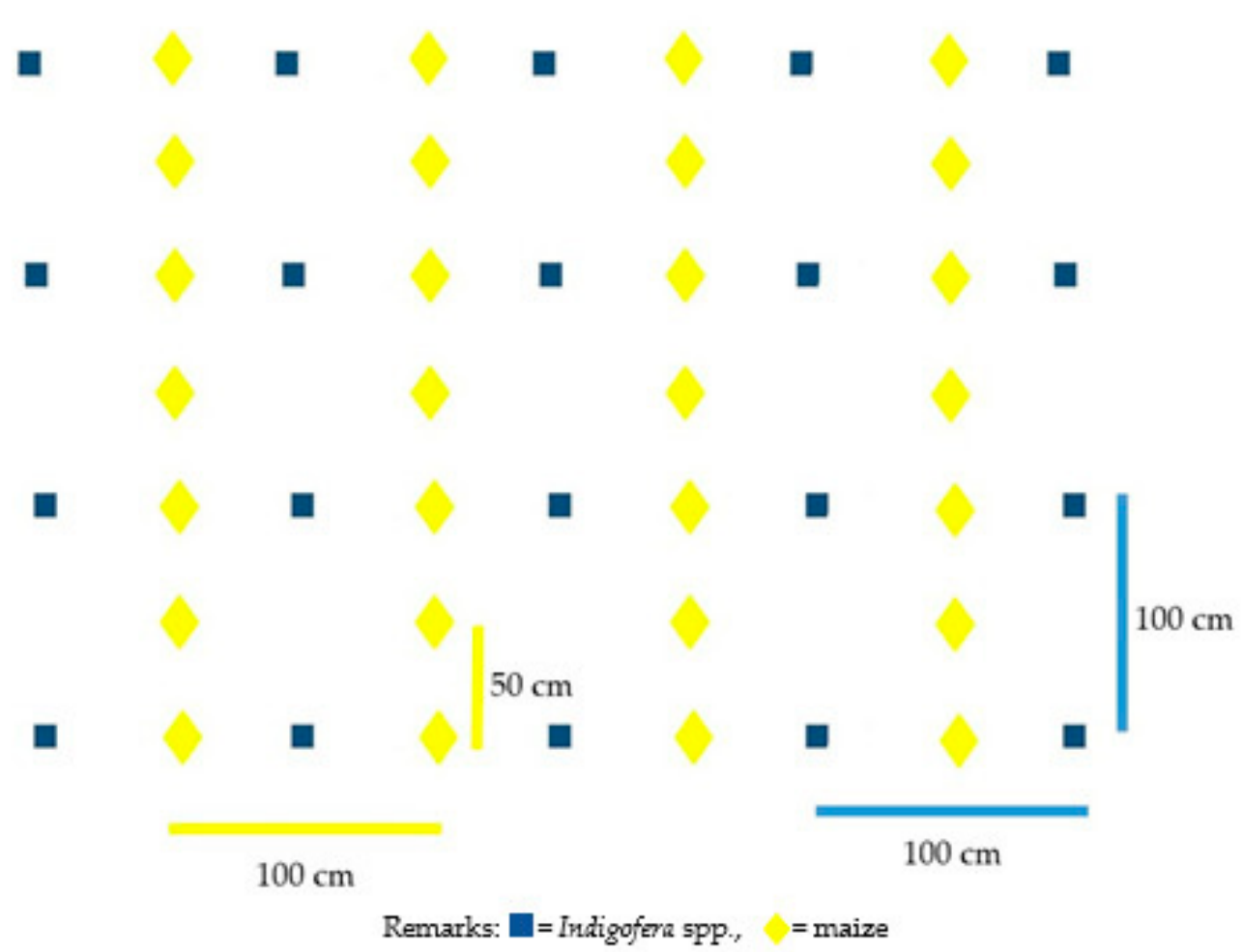

Figure 2. Cropping pattern of Indigofera spp. with maize on Timor Island.

The high TR ratio indicates that the media used is relatively fertile and that sufficient water is available (Orpa et al. 2019). According to (Rivai et al. 2015), rice husk charcoal has good aeration and drainage properties but low water holding capacity, while coco peat has both high porosity and water holding capacity. Mixing these two media with soil produces an ideal medium for the growth of I. tinctoria L. seedlings, particularly in an unshaded location ( $0 \%$ shade). By contrast, I. tinctoria L. seedlings planted in a mixture of soil and rice husk charcoal (1:2) and placed in 50\% shade resulted in a seed quality index of 0.0030 , but with a lower shoot to root ratio value (4.72). According to (Orpa et al. 2019), the low value of the root to shoot ratio indicates that the rate of the growth of shoots is lower than that for roots. This indicates that the level of nutrients contained in the mixed soil and rice husk charcoal media is lower than in the mixed soil, cocopeat, and rice husk charcoal media so that plants concentrate on forming roots to optimize nutrient absorption. Both types of media and shade treatment combinations also produced a relatively high biomass compared to other treatments, at 0.0768 and $0.0798 \mathrm{~g}$, respectively. According to (Orpa et al. 
2019), the increase in biomass indicates that photosynthesis is proceeding well, thereby resulting in increased plant growth. This is presumably due to an improvement to the growth media resulting from the addition of rice compost charcoal and/or cocopeat, with an increased soil nutrient content and improved aeration and drainage. However, both types of media require different light intensities to promote optimal seedling growth.

At three weeks of age, the I. tinctoria L. seedlings did not meet the criteria for transferring seedlings to the field, with the quality index value of the seeds failing to reach 0.09 (Bogidarwanti and Darwo 2016), with a minimum SQI value of 0.09 required to ensure a high survival rate. According to (Ariyanti and Asbur 2018), I. tinctoria L. seedlings are ready to be planted in the field at the age of 4-6 weeks, while I. suffruticosa Mill. seedlings are ready at around the age of 6-8 weeks or when the minimum seedling height is $30 \mathrm{~cm}$. The use of ready-to-plant seeds may result in seedlings that are able to compete with those growing in a natural environment, where environmental factors cannot be fully controlled.

- Planting. The viability of I. suffruticosa Mill. plants up to the age of 4 months stood at $100 \%$ for all spacings, with the results of the research showing that the spacing treatment and the application of fertilizers did not significantly affect the growth of Indigofera spp. at 4 months of age. However, I. suffruticosa Mill. planted at a spacing of $100 \times 100 \mathrm{~cm}$ showed better growth than the plants spaced at $75 \times 75 \mathrm{~cm}$ and $50 \times 50 \mathrm{~cm}$. The average increase in height, diameter, and branch of I. suffruticosa Mill. planted at a spacing of $100 \times 100 \mathrm{~cm}$ stood at $25.87 \mathrm{~cm}, 3.26 \mathrm{~mm}$, and 6.44 , respectively (Table S3). According to (Li et al. 2019), plant spacing has an effect on the final yield of a range of different types of plants. Likewise, (Azam-Ali and Squire 2002) reported that plant density depends on the soil, climate, and the type of plant grown. In extreme conditions, with poor soil and in semi-arid areas without irrigation, planting is best conducted at low density to avoid the growth of weak, weedy plants. Not only do these extreme conditions result in low yields; they also create ideal conditions for pests and diseases. With the different fertilizer treatments, the results of the analysis show that fertilizer dose sizes did not result in a significant difference in growth rates but that the application of fertilizer $(100,150$, and $200 \mathrm{~g}$ per plant) resulted in better growth in diameter and number of branches than in the case of plants planted without fertilizer $\left(0\right.$ g plant $\left.^{-1}\right)$. Similarly, the results of a study conducted by (Setiono and Azwarta 2020) show that the application of cow manure had a significant effect on plant height, stem diameter, number of leaves, and net weight of cobs per plant in maize, with the best results produced with $600 \mathrm{~g}$ of fertilizer per plant. This indicates that the soil at the study site required the addition of the appropriate amount of nutrients to facilitate growth, with the application of manure as a basic fertilizer at the beginning of the planting process adding macronutrients and some micronutrients required for plant growth, as well as improving soil structure, aggregating water holding capacity, and increasing soil permeability and the exchange of cations. Found in the study (Nyakpa et al. 2008) manure, as an organic fertilizer, plays an important role in the growth of plants due to its positive effects on the physical and chemical properties of the media. Manure can increase the media's capacity to absorb water and improve the living conditions of the microorganisms in the media, stimulating granulation and enabling available nutrient ions to trigger cell wall growth, resulting in increases to the size of the stem diameter.

The results of the research showed that the most significant factor in the cultivation of Indigofera in TTS is planting time, with the planting time having a strong effect on the leaf production of Indigofera. According to (Ariyanti and Asbur 2018), the optimal time to plant Indigofera is at the beginning of the rainy season. Therefore, the recommended time to plant Indigofera on Timor Island is in November, which receives high rainfall.

Planting at this time results in optimal growth and high leaf production. By the time of the arrival of the dry season, the plants have adapted to the environment, so there is no need for watering. However, in cases where the dry season occurs earlier than forecast, 
watering may be required. Under normal conditions, Indigofera leaves can be harvested four months after planting.

Indigofera plants are productive for about $2-4$ years, depending on the species and growing location. For example, the life cycle of Indigofera tinctoria L. on Java Island is 2-3 years (Kurniawan 2020; Ariyanti and Asbur 2018). The development cycle for the cultivation of Indigofera spp. described above throughout the four stages (germination, seedling, planting and harvesting) is very different from the cycle traditionally applied by the community (Figure 3A). The community only harvests Indigofera spp. plants found in nature, usually once a year, following the commencement of the rainy season (Figure 3B).

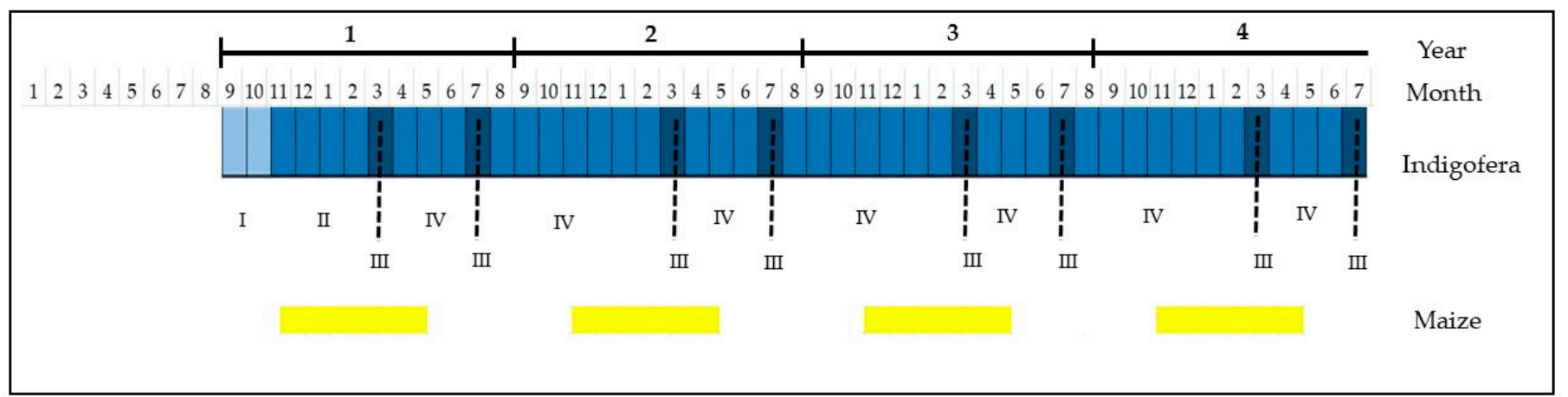

(A)

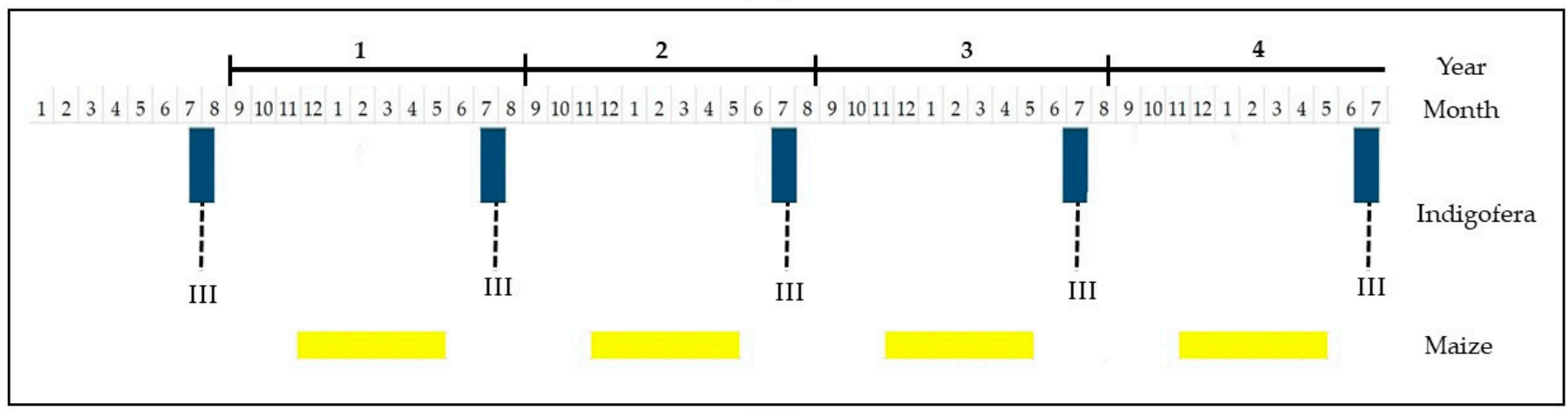

(B)

Figure 3. The production cycle for Indigofera spp. over 48 months: (A) application of cultivation techniques, (B) utilization of Indigofera spp. by the community. Notes: I = germination and seeding (1.5-2 months), II = planting (4 months), III = harvesting (4 months after planting, or when the plants are ready), IV = post-harvest maintenance/leaf pruning ( 4 months).

The initial planting of Indigofera is conducted at the beginning of the rainy season (around November) and preceded by germination and seedling (1.5-2 months before). The cultivation of Indigofera tinctoria L. on Java Island, harvesting is carried out when the plants are 4-5 months old. The next harvest is carried out 3-4 months after the first harvest or it can be harvested 3 times a year, with the life span of the plant as a dye producer being 2-3 years (Kurniawan 2020; Ariyanti and Asbur 2018). Furthermore, (Ariyanti and Asbur 2018) say that Indigofera tinctoria L. grows optimally in areas with rainfall below $1750 \mathrm{~mm}$ year ${ }^{-1}$ accompanied by a hot and humid climate. The dry condition of Timor Island (rainfall 1211-1242 $\mathrm{mm}_{\text {year }}{ }^{-1}$ ) makes the frequency of harvesting not as often as in Java, a maximum of 2 times a year. Harvesting on Timor Island is conducted 4 months after planting when the plants are in full bloom, and the leaves are colored bluish green (community experience). Harvesting is conducted in the morning at 4-6 am (Ariyanti and Asbur 2018), with the process involving pruning at the bottom (1 $\mathrm{m}$ from the bottom) (Muzzazinah et al. 2021). 
The initial harvesting takes place in March and a secondary harvest takes place in July. Likewise, maize, which is a staple crop, is planted in November and harvested in April, with the full cycle taking a year. Following the second harvest in July, the dry season arrives, during which period the plants will experience a decrease in growth. However, with the return of the rainy season, the growth of the Indigofera increases, enabling harvesting to take place in around March of the following year. Figure 3 depicts the annual production cycle.

\subsection{Processing Indigofera Leaves to Produce Indigo Paste}

After harvesting, the leaves of the Indigofera are immediately separated from the twigs, after which they are processed. This must be undertaken immediately to obtain a high yield of indigo dye. According to (Ariyanti and Asbur 2018), semi-dried or dry leaves will produce only a low yield because the $\beta$-glucosidae enzyme is more active in fresh leaves than in semi-dried or dry leaves. Indigofera leaves extract contains indican glucoside, which can be hydrolyzed to glucose and indoxyl. Indoxyl itself is a colorless indigo precursor that, in alkaline conditions, is easily oxidized, resulting in the production of blue indigo pigment.

The production of indigo paste from Indigofera leaves involves three processes these being fermentation to release the indigo precursors, removal of the leaves and oxidation of the liquor as a result of aerating under alkaline conditions caused by the addition of slaked lime $\left(\mathrm{Ca}(\mathrm{OH})_{2}\right)$, and the precipitation of the indigo dye with the slaked lime. Following these processes, the precipitate is used to produce a paste that is ready for use (Figure 4).
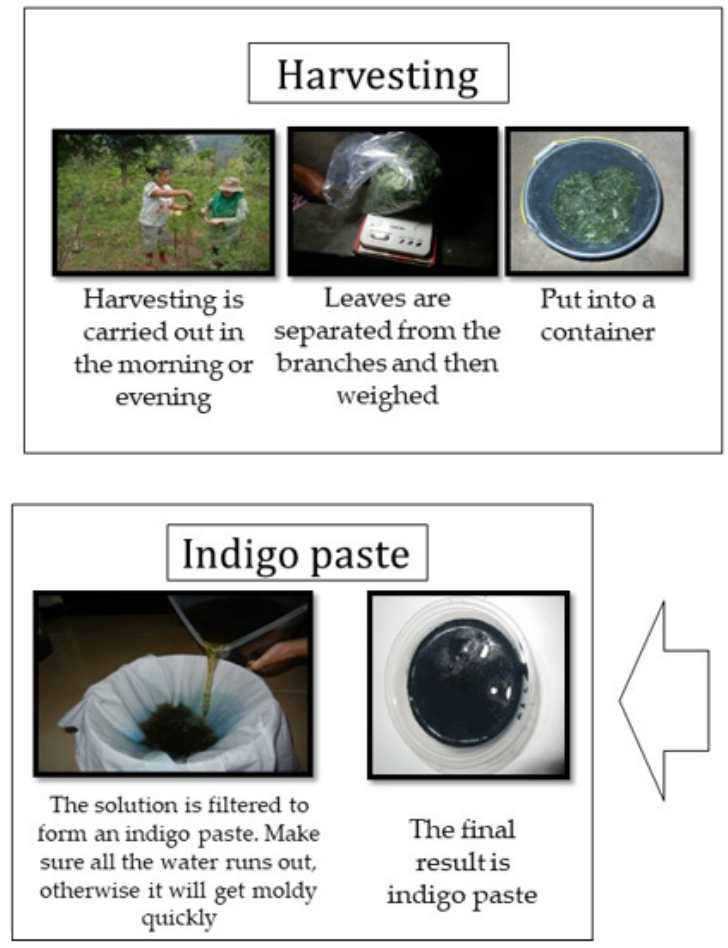
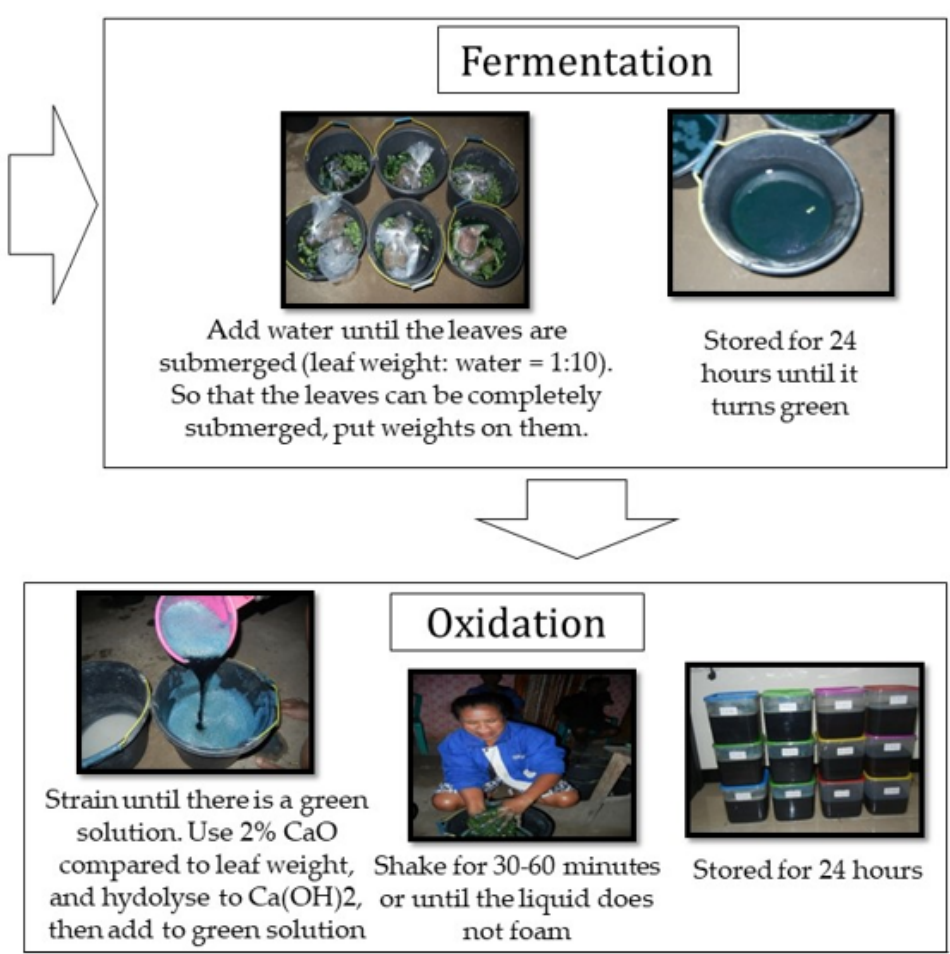

Figure 4. Process of producing paste from Indigofera leaves.

There are a number of differences between the indigo paste processing technique and the community utilization process. More details can be seen in Table 2. 
Table 2. Differences between the indigo paste processing technique and the community utilization process.

\begin{tabular}{|c|c|c|}
\hline Components & Community Utilization Process & The Indigo Paste Processing Technique \\
\hline Raw materials & Indigo leaves & Indigo leaves \\
\hline Additional materials & Clay + lime $(\mathrm{CaO})$ & Lime $(\mathrm{CaO})$ \\
\hline Volume and composition & $\begin{array}{c}\text { Depending on needs and available equipment } \\
\text { usually } 1: 10\end{array}$ & Lime $(\mathrm{CaO})$ equivalent to $2 \%$ of raw materials \\
\hline Process & $\begin{array}{ll}\text { - } & \text { Indigofera spp. leaves are pounded + water, } \\
\text { boiled, then filtered } \\
\text { - } & \text { thread soaked in black clay + lime }(\mathrm{CaO}) \\
- & \text { removed and placed in a different container } \\
\text { - } & \begin{array}{l}\text { Indigofera spp. solution is poured over the } \\
\text { clay-covered thread }\end{array} \\
- & \text { allowed to sit overnight } \\
- & \text { dried and then washed to remove clay } \\
- & \text { placed in the sun until fully dry } \\
- & \text { black thread is produced }\end{array}$ & $\begin{array}{l}\text { - } \quad \text { fermentation to release the indigo precursors } \\
\text { removal of the leaves and oxidation of the } \\
\text { liquor as a result of aerating under alkaline } \\
\text { conditions caused by the addition of slaked } \\
\text { lime }\left(\mathrm{Ca}(\mathrm{OH})_{2}\right) \text { and the precipitation of the } \\
\text { indigo dye with the slaked lime } \\
\text { stirred or crushed for } 30-60 \text { min and then } \\
\text { left for } 24 \mathrm{~h} \\
\text { the water is filtered until the indigo paste } \\
\text { precipitate is obtained }\end{array}$ \\
\hline Processing time & 4-6 days & 3 days \\
\hline Final product & Solution & Paste \\
\hline Viability period & $\begin{array}{l}\text { Discarded immediately after being used to die } \\
\text { the thread }( \pm 48 \mathrm{~h})\end{array}$ & Can be stored for a year or more \\
\hline Color produced & Black & Blue Indigo \\
\hline
\end{tabular}

\subsection{Potential Cultivation Area of Indigofera spp. on Timor Island, Indonesia}

Indigofera spp. plants have a high level of adaptability, often growing in the wild in all types of soil, with high levels of tolerance to drought, flooding, and high salinity (Campos et al. 2018). Many are found growing in coastal regions in soil with clay-sand soil characteristics and with a $\mathrm{pH}$ ranging from 6 to 7 . It grows well in locations with an average temperature of $22-28{ }^{\circ} \mathrm{C}$ and with a maximum temperature of $32{ }^{\circ} \mathrm{C}$ (Bobojonov et al. 2012). For the cultivation of plants, altitude is the first criterion that must be considered out of a number of topographical parameters. Altitude parameters are closely related to temperature parameters, with a relationship between altitude, temperature, and rainfall (Sagredo et al. 2014). I. suffruticosa Mill. can be found at altitudes of 1-1800 m asl, while I. tinctoria at $0-800 \mathrm{~m}$ asl. Both species grow in areas where the air temperature ranges between 21 and $34^{\circ} \mathrm{C}$. Generally, it is recommended that agricultural activities take place in flat areas to minimize soil erosion, in areas with soil of good quality (Kumar and Jhariya 2015). Due to impacts on environmental sustainability, cultivation on steep slopes is not recommended (Malley et al. 2006). Based on these considerations, the areas with the highest suitability scores are those with slopes of $0-3 \%$. Climatic parameters are a critically important factor for plant growth, affecting a wide range of physiological processes (Gruda 2005). Both rainfall and temperature affect plant growth in high-land areas, as shown by a number of studies (Motsa et al. 2015; Naughton et al. 2015). Air temperatures have an impact on chemical reactions and the physical properties of plants, with effects both at the cellular level and at the plant level (Gruda 2005). On Timor Island, temperatures range from between 12.2 and $27.6^{\circ} \mathrm{C}$, with a maximum temperature of $33.5^{\circ} \mathrm{C}$.

The weight of the criteria generated from the AHP is presented in Table 3. The results showed that the consistency ratio $(\mathrm{Cr})$ stood at 0.03 . This value is still below the maximum threshold $(\mathrm{Cr})$ of 0.1 . This shows that the results are valid, in accordance with the threshold recommended by (Saaty 2008).

The results show that topographic and climatic conditions have a higher weight than soil quality. These results indicate that soil quality is not a limiting factor for the successful cultivation of Indigofera spp. Soil on Timor Island has specific characteristics, as follows: dominated by medium soil texture ( $\pm 85 \%$ of the area); $\pm 47 \%$ of the area has soil conditions with $\mathrm{pH}$ 7.1, CEC 10.4, and Corg 0.97. A study by (Suriadi et al. 2021) found that soil $\mathrm{pH}$ on Timor Island is neutral to alkaline. Although the soil is alluvium, the surrounding parent 
material is made entirely of limestone. Soil derived from limestone parent material has a shallow solum of $<50 \mathrm{~cm}$, with most of it lithic. The soil also has very low organic carbon content. In terms of topographic conditions, the largest proportion of the land has a slope of $<8 \%$ ( $\pm 53 \%$ of the area), at an altitude of $<600 \mathrm{~m}$ above sea level ( $\pm 77 \%$ of the area). In terms of climatic conditions, the largest proportion of the land has an annual rainfall of $1000-1500 \mathrm{~mm}\left( \pm 84 \%\right.$ of the area), with an average temperature of $24{ }^{\circ} \mathrm{C}( \pm 69 \%)$ and a maximum temperature of $30{ }^{\circ} \mathrm{C}( \pm 48 \%)$. Timor Island is characterized by a dry climate (Suriadi et al. 2021).

Table 3. Weight of criteria resulting from pairwise comparison.

\begin{tabular}{ccccccccccc}
\hline Criteria & Text. & Ph & CEC & Corg & Alt & Slope & RF & Temp. & MaxTemp & Weight \\
\hline Text. & 1 & 2 & 5 & 4 & $1 / 5$ & 3 & $1 / 4$ & $1 / 3$ & $1 / 2$ & 0.069304429 \\
Ph & $1 / 2$ & 1 & 4 & 3 & $1 / 5$ & 2 & $1 / 5$ & $1 / 4$ & $1 / 3$ & 0.049803415 \\
CEC & $1 / 5$ & $1 / 4$ & 1 & $1 / 2$ & $1 / 9$ & $1 / 3$ & $1 / 8$ & $1 / 7$ & $1 / 6$ & 0.017784182 \\
Corg & $1 / 4$ & $1 / 3$ & 2 & 1 & $1 / 8$ & $1 / 2$ & $1 / 7$ & $1 / 6$ & $1 / 5$ & 0.024925978 \\
Alt & 5 & 6 & 9 & 8 & 1 & 7 & 2 & 3 & 4 & 0.306953228 \\
Slope & $1 / 3$ & $1 / 2$ & 3 & 2 & $1 / 7$ & 1 & $1 / 6$ & $1 / 5$ & $1 / 4$ & 0.034439834 \\
RF & 4 & 5 & 8 & 7 & $1 / 2$ & 6 & 1 & 2 & 3 & 0.22058476 \\
Temp. & 3 & 4 & 7 & 6 & $1 / 3$ & 5 & $1 / 2$ & 1 & 2 & 0.15394614 \\
MaxTemp & 2 & 3 & 6 & 5 & $1 / 4$ & 4 & $1 / 3$ & $1 / 2$ & 1 & 0.122258035 \\
\hline
\end{tabular}

Notes: Text: texture, $\mathrm{CEC}=$ cation exchange capacity, $\mathrm{Corg}=\mathrm{C}$ organic, Alt $=$ altitude, $\mathrm{RF}=$ rainfall, Temp. $=$ temperature, MaxTemp $=$ maximum temperature.

The results of the land suitability analysis for Indigofera spp. on Timor Island are presented in Figure 5. Land that is not suitable for the cultivation of Indigofera spp. plants covers an area of less than $\pm 1 \%$ of the total area of the island. The unsuitable land is mainly located around mountain peaks, characterized by a combination of physical properties that do not permit crop cultivation, including steeper slopes and very low temperatures. This land is generally not cultivated, with the land cover consisting of forests. Thus, almost 99 percent of the land on Timor Island is suitable for the cultivation of indigo plants. The degree of suitability varies, however, from very suitable (S1) to marginally suitable (S3), with the greatest proportion of the land falling into the very suitable (S1) category, with land in this category covering a total area of \pm 1.3 million ha.

To determine the suitability of land for the cultivation of Indigofera spp., a land availability analysis was conducted, based on considerations related to land cover and land-use conditions. Of the Indonesian territory on the Island of Timor that consists of agricultural land, 453,931 ha has suitable land conditions for indigo cultivation. However, the development of land for this purpose is directed at land not covered by forest and/or that has been used for plantations or other agricultural uses. Thus, 369,836 ha of the Indonesian territories of Timor Island are available for the cultivation of Indigo, with most of this land consisting of abandoned land, mostly either open land or covered with shrubs and grasslands (Figure 6).

In Indonesia, measures to develop the cultivation of Indigofera spp. could also play a role in accelerating land rehabilitation, considering that a large proportion of the suitable areas consist of critical land $( \pm 80 \%)$, with more than $60 \%$ of this area located outside forest areas (Other Use Area (Areal Penggunaan Lain, APL)). Measures to accelerate land rehabilitation initiatives are important, particularly in the context of the threat of deforestation in the tropical mountain forests of Timor (Pujiono et al. 2019). The most suitable land in critical APL areas could be prioritized for the development of Indigofera spp. ( \pm 163 thousand ha). The distribution of the area based on the level of criticality of the land and land function status is presented in Table 4. 


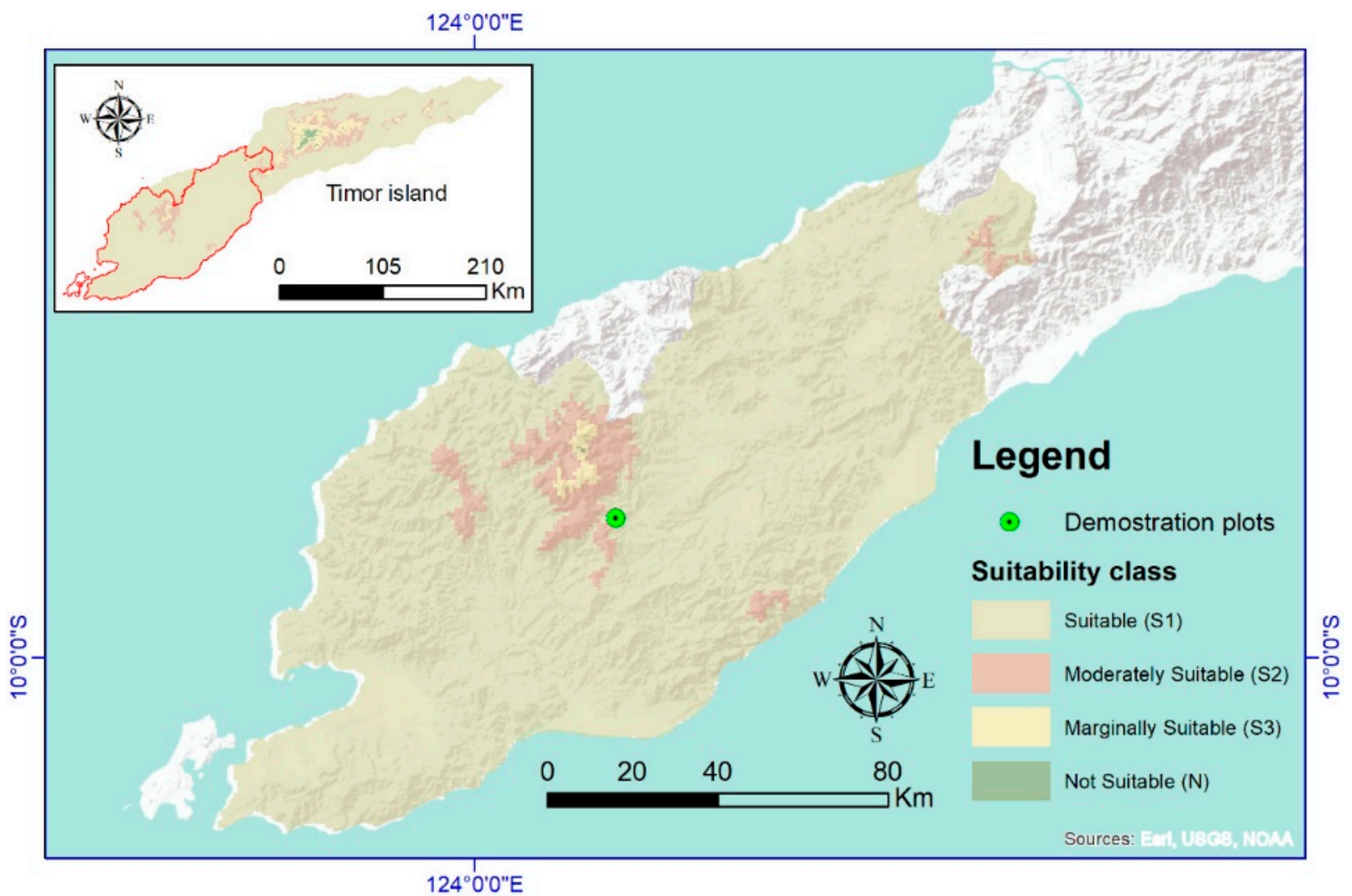

Figure 5. Land suitability map Indigo on Timor Island.

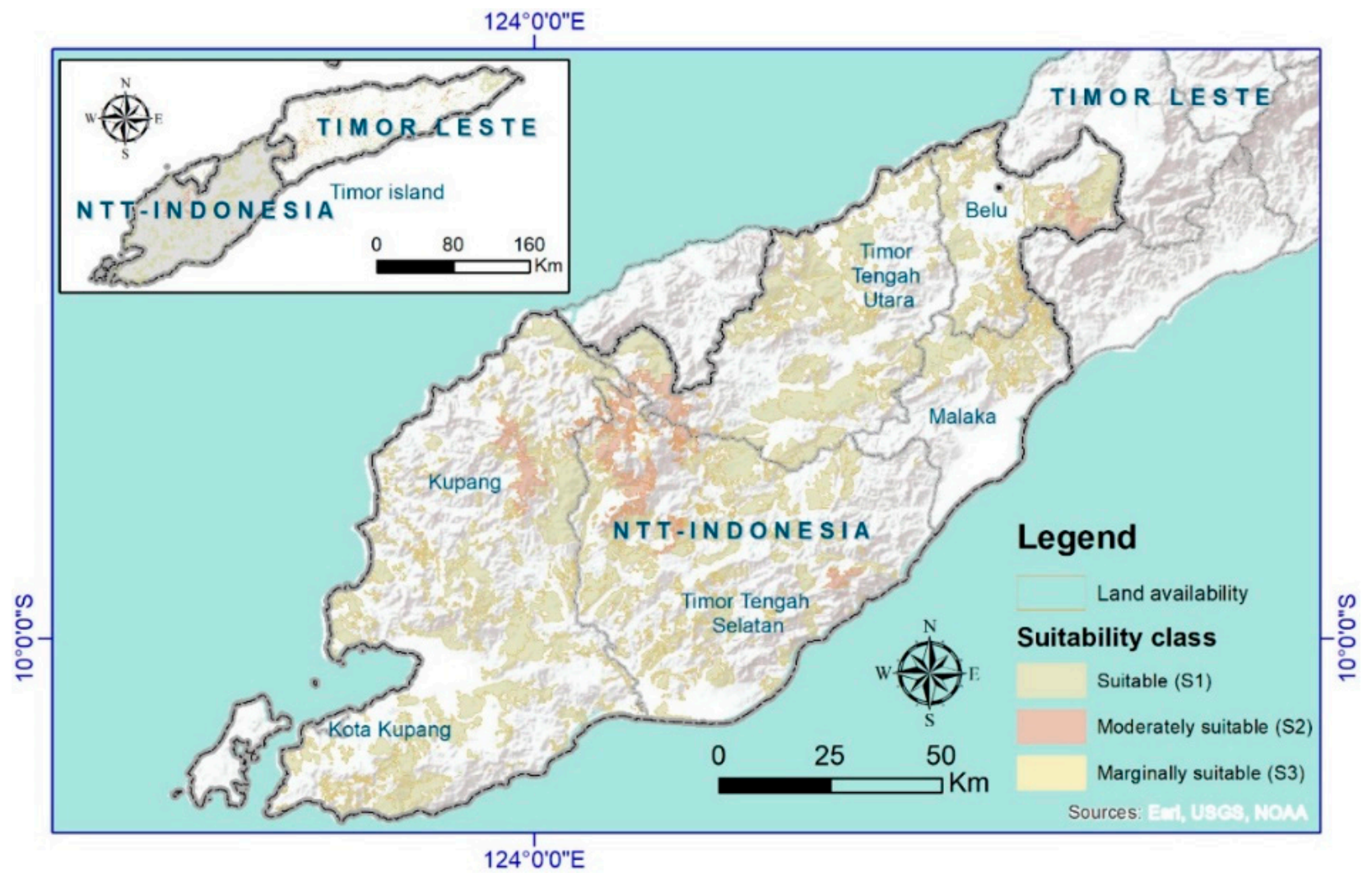

Figure 6. Land availability map for the cultivation of Indigo on Timor Island. 
Table 4. Area available for the cultivation of indigo cultivation based on land function status and land criticality for the prioritization of rehabilitation efforts.

\begin{tabular}{|c|c|c|c|c|c|}
\hline \multicolumn{2}{|c|}{ Category } & \multicolumn{4}{|c|}{ Land Use Function (ha) } \\
\hline Suitability & Criticality & Protection & Production & Conservation & APL \\
\hline S1 & Moderately Critical & 34,599 & 41,749 & 201 & 140,556 \\
\hline S1 & Critical & 14,363 & 8038 & 179 & 22,297 \\
\hline S1 & Very Critical & 667 & 40 & - & 171 \\
\hline S2 & Moderately Critical & 10,143 & 720 & 805 & 12,969 \\
\hline S2 & Critical & 3342 & 34 & 177 & 2304 \\
\hline S2 & Very Critical & 161 & - & - & 117 \\
\hline $\mathrm{S} 3$ & Moderately Critical & 281 & - & 490 & 16 \\
\hline S3 & Critical & 43 & - & 33 & - \\
\hline \multicolumn{2}{|c|}{ Total } & 63,599 & 50,581 & 1885 & 178,429 \\
\hline
\end{tabular}

Remark: S1 = suitable, S2 = moderately suitable, S3= marginally suitable

\subsection{Economic Analysis of the Cultivation of Indigofera spp.}

3.5.1. Feasibility Analysis

A business feasibility assessment was conducted to determine the feasibility of the development of Indigofera spp., including cultivation activities and the production of indigo paste. Indigofera spp. cultivation activities includes nursery, nursery maintenance, planting preparation, planting, and plant maintenance. The production of indigo paste activities includes harvesting and processing the paste.

\section{Cost}

The cost of activities associated with the cultivation of Indigofera spp. and the processing of leaves to produce indigo paste were assessed. The following Table 5 contains a list of the type of expenditures involved and their magnitude:

Table 5. Types of expenditure involved in the cultivation of Indigofera spp. and the production of indigo paste in 2021.

\begin{tabular}{lccr}
\multicolumn{1}{c}{ Type of Expenditure } & Units Required & Units & $\begin{array}{c}\text { Total Expenditure } \\
\text { (IDR) }\end{array}$ \\
\hline a. Fixed operating costs & & & 210,000 \\
Purchase of paranets & 7 & $\mathrm{~m}$ & $1,050,000$ \\
Purchase of tarpaulins & 175 & fruit & 560,000 \\
Purchase of dippers & 56 & $\mathrm{~m}$ & $1,120,000$ \\
Purchase of filtering cloth & 56 & $\mathrm{Kg}$ & - \\
b. Variable Operating Costs & & $\mathrm{Kg}$ & $1,800,000$ \\
Purchase of polybags & 40 & $\mathrm{Kg}$ & $2,500,000$ \\
Purchase of manure for the nursery & 100 & Liter & $1,000,000$ \\
Purchase of manure for planting & 200 & $\mathrm{Kg}$ & $14,000,000$ \\
Purchase of water for production of paste & 28,000 & $2,800,000$ \\
Purchase of quicklime & 56 & $3,250,000$ \\
Wages for filling polybags and sowing & 50 & labor day & 325,000 \\
Nursery maintenance fees & 5 & labor day & $3,250,000$ \\
Wages for digging holes & 50 & labor day & $1,300,000$ \\
Wages for planting & 20 & labor day & $47,450,000$ \\
Wages for maintenance work & 730 & labor day & $3,640,000$ \\
Wages for harvesting and processing leaves & 56 & labor day & $7,280,000$ \\
Wages for paste production & 112 & labor day & $95,535,000$ \\
\hline Total & & & \\
\hline
\end{tabular}

Income

Income calculation begins with Indigofera productivity, with total production calculated based on Indigofera leaf productivity per unit area. In 1 ha with a spacing of $100 \times 100 \mathrm{~cm}$, there will be 10,000 plants. Each individual plant produces an average of $35 \mathrm{~g}$ of Indigofera leaves per harvest. Harvesting on Timor Island can be done twice a year. Therefore, in 
1 year, the production of Indigofera leaves is $700 \mathrm{~kg} \mathrm{ha}^{-1}$. Based on the productive age of the plant, the Indigofera cultivation cycle is 4 years. Thus, the productivity and total production of Indigofera leaves in one business cycle for 4 years is $2800 \mathrm{~kg} \mathrm{ha}^{-1}$.

The next step in the income calculation process is to calculate the yield of paste. Based on the results of the study, it was found that when $300 \mathrm{~g}$ of Indigofera leaves were added to $6 \mathrm{~g}$ of lime (2\%) and 31 of water, this yielded $177 \mathrm{~g}$ of paste (Agustarini et al. 2021). The calculation of paste yields based on the research activities is presented in Table 6.

Table 6. Indigo paste production from 1 hectare of Indigofera plant.

\begin{tabular}{lrc}
\hline \multicolumn{1}{c}{ Indigo Paste Yield in 1 Year } & Value & Units \\
\hline Paste yield per kg (1000 g) of Indigofera leaves & 390 & $\mathrm{~g}$ \\
Productivity of Indigofera leaves per ha per harvest & 350 & $\mathrm{~kg}$ \\
Paste yielded in a single harvest per hectare & 136.50 & $\mathrm{~kg}$ \\
Paste yielded per year per hectare & 273 & $\mathrm{~kg}$ \\
\hline
\end{tabular}

The productivity of paste yields per hectare per year is $273 \mathrm{~kg}$ (Table 6). The price of indigo paste is relatively inelastic due to both the supply and demand for indigo paste being relatively stable. Thus far, there has been no substitution of natural blue dye apart from Indigofera, and production competition is still limited. There is no large industry that produces an indigo paste that will potentially monopolize the market price. The price used for income analysis was the price of indigo paste in 2021, based on the selling price of indigo paste in the market place (IDR $110,000 \mathrm{~kg}^{-1}$, or USD 7.75). Therefore, the income derived from producing indigo paste is IDR 30,030,000 ha-1 year ${ }^{-1}$ (or USD 2117) and income during the cultivation cycle is IDR $120,120,000 \mathrm{ha}^{-1}$ (or USD 8469).

\section{Results of the Financial Analysis}

In conducting a financial feasibility analysis, it is necessary to consider changes in the value of currency over time. The cash flow on which the calculation of the investment eligibility criteria is based runs over a fairly long period of time (4 years). A calculation of the changes in the value of money over this period is calculated by including discounts in the analysis. Discounts are needed to convert the expected future flow of resources into an estimated present value (Riyanto 2018). The results of the financial analysis for the production of indigo paste are presented in Table 7, based on an assumption of a discount factor of $8 \%$, based on the Bank Rakyat Indonesia credit interest rate in 2021. This follows (Nurmalina et al. 2018), who state that one of the factors for determining the discount rate is loan interest rates.

Table 7. The results of the financial analysis into the production of indigo paste with a factor discount of $8 \%$ over a 4 -year business cycle.

\begin{tabular}{cc}
\hline Investment Parameters & Value \\
\hline NPV & IDR 18,526,006 or USD 1306.145 \\
BCR & 1.23 \\
IRR & $126 \%$ \\
BEP & Second year \\
\hline
\end{tabular}

The results of the analysis demonstrate the feasibility of indigo paste production. This is shown by the values of the investment parameters, with the NPV showing a positive value, with the BCR above 1, with the IRR above the discount rate, and the BEP within the period of the business cycle. The analysis shows that the production of indigo paste has the potential to yield profits of IDR 4631,501.50 ha ${ }^{-1}$ year $^{-1}$, or USD 326,536 (exchange rate: USD 1 = IDR 14,183.73).

El Nino events impacted Timor Island in 2006-2007 (Kieft and Soekarjo 2007), with further impacts from La Nina in 2009 (Kota and Adiningtyas 2010), with these climatic 
anomalies having a severe impact on Timor's agricultural sector and on community welfare. The results of research related to the cultivation of Indigofera spp. show that climatic conditions are one of the most important factors for the cultivation of this plant, with significant implications for productivity. Thus, it can be concluded that the climatic anomalies associated with El Nino and La Nina would impact the productivity of agricultural crops.

With El Nino conditions resulting in extreme dry seasons, when these conditions occur, it is essential to water plants so that they do not die. To determine the impact of this on the cultivation of Indigofera spp., a sensitivity analysis was conducted, taking into account factors including decreased productivity and the increased production costs resulting from the need for watering.

The analysis involved two scenarios for decreased productivity, with the first assuming

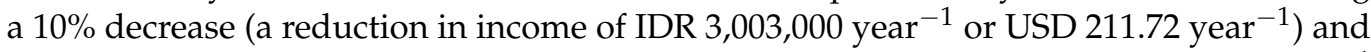
with the second assuming a 20\% decrease (a reduction in income of IDR 6,006,000 year ${ }^{-1}$ or USD 423.44 year $^{-1}$ ). The two scenarios involving increased production costs are respectively based on the need for watering activities with an intensity of 1 month in 1 year (resulting in an additional cost of IDR 3,741,497 year ${ }^{-1}$ or USD 263.79 year $^{-1}$ ) and on an intensity of 2 months in 1 year (resulting in an additional cost of IDR 7,482,993 year or $^{-1}$ USD 527.58 year $^{-1}$ ), as shown in Table 8.

Table 8. Results of sensitivity analysis for the decreased leaf production of Indigofera spp.

\begin{tabular}{ccc}
\hline \multirow{2}{*}{ Investment Parameters } & \multicolumn{2}{c}{ Productivity from Indigofera spp. } \\
\cline { 2 - 3 } & Decline of $\mathbf{1 0} \%$ & Decline of $\mathbf{2 0} \%$ \\
\hline NPV & IDR $8,581,689$ or USD 605.0375 & IDR $-1,364,628$ or USD \\
BCR & 1.11 & -96.21 \\
IRR & $51 \%$ & 0.98 \\
BEP & Third year & 0.02 \\
\hline
\end{tabular}

The results of the sensitivity analysis for the decreased leaf production of Indigofera show that the production of Indigofera paste would remain feasible if the production of Indigofera leaves decreased by a figure not exceeding $10 \%$. However, if the decrease is greater than $10 \%$, then the production of indigo paste is not feasible. Sensitivity analysis is conducted if there is an increase in costs due to watering activities. It is carried out in 2 scenarios, namely 1 and 2 months of watering in a 1 year planting period (Table 9).

Table 9. Results of sensitivity analysis to the increase in costs due to watering activities.

\begin{tabular}{ccc}
\hline \multirow{2}{*}{ Investment Parameters } & \multicolumn{2}{c}{ Period for Which Watering Is Required in One Year } \\
\cline { 2 - 3 } & $\mathbf{1}$ Month & 2 Months \\
\hline \multirow{2}{*}{ NPV } & IDR 6,135,695 or USD 432.5868 & IDR $-6,256,616$ or USD \\
BCR & 1.07 & -441.1122 \\
IRR & $38 \%$ & 0.94 \\
BEP & Third year & $-19 \%$ \\
\end{tabular}

The results of this sensitivity analysis indicate that indigo paste production activities remain feasible if watering is required for a maximum of 1 month in 1 year. However, when watering is required for longer periods than this, indigo production becomes unfeasible.

3.5.2. Potential Economic and Social Value to Be Derived from the Development of Indigofera spp.

The potential economic value of Indigofera development is from the indigo paste selling activities in which its raw material is harvested from Indigofera potential cultivation areas. Based on the results of the various analyses, a number of findings related to the 
development of Indigofera on Timor Island were obtained, including the following: the potential area to be prioritized for development covers \pm 163 thousand ha; I. suffruticosa Mill. can generate production yields of $700 \mathrm{~kg} \mathrm{ha}^{-1}$; resulting in yields of indigo paste of $273 \mathrm{~kg} \mathrm{ha}^{-1}$, with the potential to generate profits of IDR 4,631,501.50 ha $\mathrm{hear}^{-1}$ or USD 326.54 (exchange rate: 14,183.73). The potential economic value to be derived from the development of Indigofera on Timor Island is distinguished based on three plantings scenarios: $100 \%$ targeted area development with intercropping (scenario 1); $50 \%$ targeted area development with intercropping (scenario 2); and 25\% targeted area development with intercropping (scenario 3). A comprehensive outline of the potential economic and social value to be derived from the development of Indigofera can be seen in Table 10.

Table 10. Potential economic and social value to be derived from the development of Indigofera.

\begin{tabular}{lccc}
\hline \multicolumn{1}{c}{ Parameter } & $\begin{array}{c}\text { Scenario 1 } \\
(\mathbf{1 0 0 \%} \text { Target Area) }\end{array}$ & $\begin{array}{c}\text { Scenario 2 } \\
\text { (50\% Target Area) }\end{array}$ & $\begin{array}{c}\text { Scenario 3 } \\
\text { (25\% Target Area) }\end{array}$ \\
\hline Area (Ha) & 163,000 & 81,500 & 40,750 \\
Potential supply of raw leaves (tons year ${ }^{-1}$ ) & 114,100 & 57,050 & 28,525 \\
Potential supply of indigo paste for dye (tons year ${ }^{-1}$ ) & 44.5 & 22.25 & 11.12 \\
Economic potential & IDR 754,934,744,500 & IDR 377,467,372,250 & IDR 188,733,686,125 \\
Potential social impact in terms of employment & or USD 53,225.40 & or USD 26,612.70 & or USD 13,306.35 \\
(labor day)-per year & $42,054,000$ & $21,027,000$ & $10,513,500$ \\
\hline
\end{tabular}

The potential social impact to be derived from the development of Indigofera takes the form of employment, given that the processes involved are labor-intensive. This potential is demonstrated in Figure 7, which shows that wages account for the largest proportion of the operational costs associated with the development of Indigofera (70\%). The wage component for 4 years of Indigofera production cycle absorbs 1023 labor day (years 1: 348 labor day, years 2-4: 225 labor day) consists of the cultivation of Indigofera and the producing of indigo paste. In the first year, we need more labor for the cultivation activities. In the second to fourth year we only have maintenance and indigo paste production. In the cultivation of Indigofera, the wage component reaches $84 \%$ of the total cost of wages, while the proportion of the manufacture of indigo paste reaches $16 \%$. Thus, this sector is suitable to be developed as it is able to absorb many workers in the rural sector.

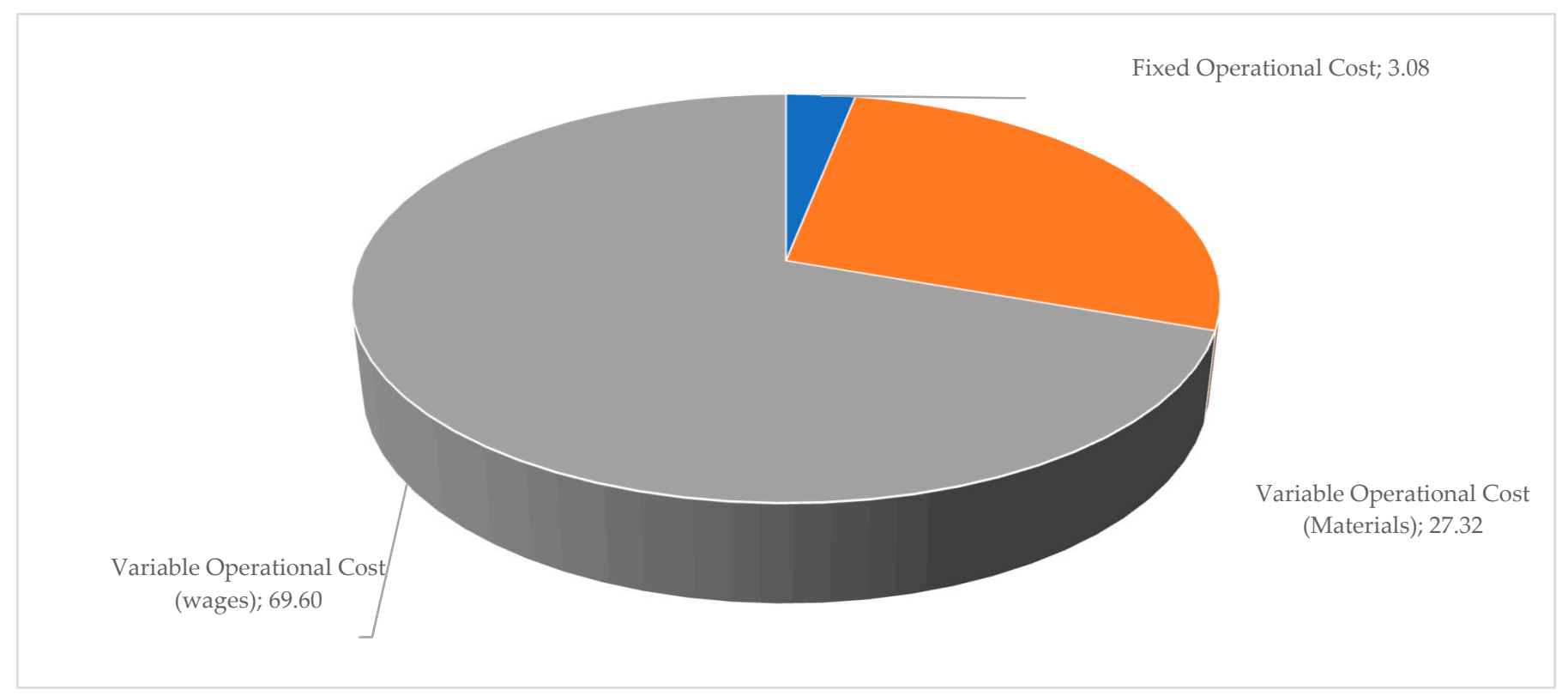

Figure 7. Composition of costs related to the development of Indigofera. 
Ikat weaving also has economic potential as a tourist attraction. Weaving from this region has significant aesthetic value and plays a major role in establishing cultural identity (Susanti 2021). Thus, it has the potential to act as a form of cultural tourist attraction that could create value for NTT as a market for tourists.

As shown by a study conducted by (Muda and Suwito 2019), ikat weaving could drive increased tourist visits to the region, with significant potential economic benefits for the community. The development of weaving crafts has the potential to generate significant employment and to reduce the unemployment rate. Thus, this innovation has the potential to generate strong positive social value (Salma et al. 2018). There is good potential to develop the ikat weaving business, given that most craft people work individually, with very few working together in groups (Muda and Suwito 2019). Weaving has strong market potential due to its recognition as an environmentally friendly art product by upper-middle consumers. According to (Samadara 2018), both national and international tourists prefer to buy ikat from Sumba with natural dye compared to synthetic dyes.

Together with increasing public awareness of the negative effects of synthetic colors on health and the environment, the market for natural dyes has good prospects (Salma et al. 2018). Therefore, ikat weaving can be regarded as a form of cultural heritage that could be developed through a community empowerment approach to generate significant positive economic and social benefits for members of communities in rural areas.

\subsection{Development Strategy the Sustainable Use of Indigofera Leaves to Produce Natural Dyes}

A development strategy for the sustainable use of Indigofera leaves to produce natural dye was formulated through a quantitative SWOT analysis. A quantitative SWOT analysis may be used to conduct an evaluation according to specific desired parameters and to develop management strategies (White et al. 2015). The main advantage of the SWOT approach is to show current and possible future constraints related to implementing a proposed initiative (Johnson et al. 1989). The SWOT analysis approach is an effective technique to formulate strategies (Hill and Westbrook 1997) because it categorizes factors related to the proposed initiative as either internal (strengths, weaknesses) or external (opportunities, threats) (Shrestha et al. 2004). Therefore, the approach can provide insights into how to transform threats into opportunities and offset weaknesses into strengths (Wang 2010; Liu 2013).

The SWOT diagram for the development of the use of Indigofera leaves as a natural dye in a sustainable manner on Timor Island, Indonesia, was constructed according to interviews with experts. Strengths and weaknesses are categorized as internal factors, and opportunities and threats are categorized as external factors (Table 11).

The determination of weights in the SWOT-AHP model is based on the results of comparisons between SWOT components using pairwise comparisons. The results of the analysis show that the value of the consistency ratio $(\mathrm{Cr})$ is 0.03 for external factors and 0.04 for internal factors. This value is still below the maximum allowable $\mathrm{Cr}$ of 0.1 , following the recommendations of (Saaty 2008). The results of the SWOT-AHP analysis show that the coordinate value for the internal factors stands at 2.10, while the external factor stands at 2.32 (Tables S5 and S6). Based on the position and action evaluation matrix strategy, there are four quadrant strategies: aggressive, competitive, defensive, and conservative (David et al. 2019).

These results indicate that the strategy for the production of Indigofera spp. on Timor Island lies in quadrant I, indicating that the strategy should be implemented aggressively. An aggressive strategy's leverage is the existing strengths and opportunities, rather than using defensive options to minimize weaknesses and threats (Rauch 2007).

Local wisdom relates not only to providing livelihoods and sustaining the lives of local communities but as also as a means to strengthen ecological sustainability and to leverage the community's unique resources to stimulate the sustainability of local wisdom itself (Lake et al. 2018). The strategy for the development of Indigofera spp. on Timor Island involves leveraging the community's culture and wisdom related to the use of this plant 
acquired over generations, as a result of which it has developed the appropriate cultivation techniques, which consist of knowledge of the right time for planting, following good cultivation practices, and using appropriate planting materials. This provides a strong basis for leveraging the development of indigo paste in suitable areas to capture significant economic and social opportunities.

Table 11. Diagram of the SWOT analysis for the sustainable development of Indigofera to produce natural dyes.

\begin{tabular}{|c|c|c|}
\hline \multirow{8}{*}{ Internal factor } & Strength & Weakness \\
\hline & $\begin{array}{l}\text { Communities in the region are accustomed to agricultural } \\
\text { cultivation activities }\end{array}$ & $\begin{array}{l}\text { Community members do not yet cultivate } \\
\text { Indigofera, but gather it from the wild }\end{array}$ \\
\hline & Indigofera grows naturally on Timor Island & $\begin{array}{l}\text { Communities are not yet familiar with techniques } \\
\text { for cultivating Indigofera }\end{array}$ \\
\hline & $\begin{array}{l}\text { High potential Indigofera that grows naturally and can be } \\
\text { collected by members of the community }\end{array}$ & $\begin{array}{l}\text { The process of producing natural dye from } \\
\text { Indigofera is more complicated than the process of } \\
\text { producing other types of natural dyes }\end{array}$ \\
\hline & $\begin{array}{l}\text { Strong willingness of community members to participate } \\
\text { in cultivating Indigofera, which is usually conducted } \\
\text { through collective cooperation }\end{array}$ & $\begin{array}{l}\text { Communities are not yet familiar with the } \\
\text { processes for producing indigo paste of sufficient } \\
\text { quality to compete with other products }\end{array}$ \\
\hline & $\begin{array}{l}\text { Wide availability of land suitable for the cultivation } \\
\text { of Indigofera }\end{array}$ & $\begin{array}{l}\text { Low general levels of education may constrain the } \\
\text { transfer of knowledge related to the cultivation } \\
\text { and processing techniques }\end{array}$ \\
\hline & $\begin{array}{l}\text { Communities have a strong cultural tradition of weaving } \\
\text { using natural dyes }\end{array}$ & \\
\hline & $\begin{array}{l}\text { The use of Indigofera is a natural dye is widely accepted as } \\
\text { part of local cultural traditions, preceding the use of } \\
\text { synthetic dyes }\end{array}$ & \\
\hline \multirow{10}{*}{ External factor } & Opportunity & Threat \\
\hline & $\begin{array}{l}\text { Increased farmer incomes from the production of indigo } \\
\text { paste from Indigofera leaves }\end{array}$ & $\begin{array}{l}\text { Unpredictable climatic conditions due to global } \\
\text { climate change }\end{array}$ \\
\hline & $\begin{array}{l}\text { Increased weaver incomes from the sale of cloth using } \\
\text { natural dyes }\end{array}$ & $\begin{array}{l}\text { The presence of synthetic dyes that makes } \\
\text { weaving more efficient }\end{array}$ \\
\hline & $\begin{array}{l}\text { Indigofera can be intercropped with food crops without } \\
\text { negative impact on the growth of any of the crops } \\
\text { involved }\end{array}$ & $\begin{array}{l}\text { Paste production is inefficient and manufacturing } \\
\text { costs are high due to increased paste production } \\
\text { not balanced by the availability of raw materials }\end{array}$ \\
\hline & $\begin{array}{l}\text { Indigofera has good potential for use to rehabilitate } \\
\text { critical land }\end{array}$ & \\
\hline & There are good prospective markets for indigo paste & \\
\hline & $\begin{array}{l}\text { The technology required for the production of indigo } \\
\text { paste is available }\end{array}$ & \\
\hline & Trend back to nature & \\
\hline & $\begin{array}{l}\text { Increased awareness of the need for environmental and } \\
\text { occupational safety }\end{array}$ & \\
\hline & $\begin{array}{l}\text { Limited availability of plants that produce natural } \\
\text { blue dye }\end{array}$ & \\
\hline
\end{tabular}

Based on the SWOT-AHP analysis, it would be possible for the regional government of NTT to formulate a number of strategies for the development of Indigofera spp. on Timor Island, including the introduction of Indigofera spp. as an agro-industry commodity and its use for the rehabilitation of critical lands. These strategies could be implemented by developing partnerships with the private sector to increase the potential sale of indigo paste, 
to expand markets, and to increase community capacity is to cultivate and process the plant. A number of stakeholders and actors could be involved in this initiative, including women's farmer groups, Dewan Kerajinan Nasional Daerah/Dekranasda (the Regional National Crafts Council), the Industry and Trade Office, the Women's Empowerment Service, the Agriculture and Plantation Service extension agencies, and private companies. Support for women's capacity building in terms of education is needed for the regeneration or further development needs. This is reinforced by (Chisamya et al. 2012), which states that by being educated, girls experienced a transformation of the inequitable gender relations they faced in society. Related to agriculture, although in Indonesia it is dominated by men, women appear to have equal access to productive resources, such as land and inputs, and greater control over household income than men (Akter et al. 2017). Funding and financing for these strategies could be sourced from related agencies, grant funds, business service agency (Badan Layanan Umum, BLU), and mutual cooperation funds managed by farmer groups.

Thus far, neither the NTT provincial government nor district governments have promulgated regulations related to the preservation of $i k a t$ or the use of natural dyes. Regional regulations could play a significant role in supporting strategies to develop the commodity, to create predictability and legal certainty, and to demonstrate a clear commitment to the development of cultural industries in NTT (Setiawan and Suwarningdyah 2014). In addition, local regulations related to weaving and tourism could play a strong role in facilitating the achievement of SDG 8 targets.

\section{Conclusions}

The people of Timor Island are familiar with a range of plants that can be used to produce natural dyes, one of which is Indigofera spp. (I. tinctoria L. and I. suffruticosa Mill.), which is generally used to produce a black dye for $i k a t$ fabrics made by the community.

The cultivation of Indigofera is conducted in three stages: germination, seeding, and planting. Sowing media plays an important role in increasing the germination rate, with the best sowing media for the germination of I. tinctoria L. being sand media. At the seedling stage of I. tinctoria L, a mixed media consisting of soil, cocopeat, and rice husk charcoal (1:2:2) and placed in an unshaded area ( $0 \%)$ and mixed media consisting of soil and rice husk charcoal (1:2) and placed in 50\% shade resulted in the highest biomass and the best quality index. At the planting stage of I. suffruticosa Mill., a spacing of $100 \times 100 \mathrm{~cm}$ resulted in the best increases in height, diameter, and number of branches, while the use of fertilizer $(100,150$, and $200 \mathrm{~g}$ plantings) resulted in better growth than without the use of fertilizer. Providing $100 \mathrm{~g}$ of fertilizer per plant results in the best results in terms of height, diameter, and number of branches.

Indigo paste is produced by adding quicklime $\mathrm{CaO}$ equivalent to $2 \%$ of the weight of the leaves and water equivalent to 10 times the weight of the leaves. This technique is more time-efficient and results in the production of a higher quality paste with a longer shelf life than through the techniques currently applied by the community.

The potential area suitable for the development of Indigofera spp. on Timor Island covers $\pm 163,000$ ha. The results of the financial feasibility analysis showed that the processing of Indigofera spp. to produce indigo paste is feasible. The results of the sensitivity analysis show that the tolerable decrease in production levels is only $10 \%$, with a maximum of one month of watering in a year for the production of indigo paste to remain feasible. The total potential supply of raw materials to produce indigo paste from Timor Island stands at 11-44 tons/year, with the economic potential standing at USD 13-53 million/year. The cultivation and processing activities are labor-intensive, requiring a workforce of 1032 person/ha during the Indigofera spp. production cycle (4 years).

Strategies to develop the cultivation and processing of Indigofera spp. on Timor Island could be conducted aggressively by leveraging the identified strengths related to the cultivation of Indigofera spp. In particular, this would involve deleveraging local wisdom and cultural traditions related to the use of Indigofera spp. over generations by applying the appropriate cultivation techniques, together with innovations in the indigo 
paste production process and the development of suitable areas to capture economic opportunities.

Supplementary Materials: The following are available online at https://www.mdpi.com/article/10 .3390/economies10020049/s1, Figure S1: Steps for Indigofera Land Suitability_Land Availability Analysis; Table S1. Effect of scarification and media on the percentage of germination of Indigofera spp. seeds; Table S2. The effect of media on germination percentage; Table S3. Effect of shade and media on growth parameters of height, diameter, number of branches, leaf production, and percent survival of Indigofera spp. seedlings; Table S4. The effect of spacing and manure application on increasing growth in height, diameter, and number of branches of Indigofera spp. four (4) months after planting; Table S5. Internal strategic factors based on weights, ratings, and scores; Table S6. Internal strategic factors based on weights, ratings, and scores.

Author Contributions: Each author (R.A., Y.H., Y.A., W.C.A., D.Y., R.A.F., G.E.S., A.H., H.L.T., W.I. and A.P.) has equal work as the main contributor who equally conceived and designed the outline of the manuscript, collected and contributed data, performed the analysis, provided constructive feedback for each section, and wrote and edited the manuscript. All authors have read and agreed to the published version of the manuscript.

Funding: This research was funded by ACIAR, Kanoppi Project, FST/2016/141.

Institutional Review Board Statement: As the study does not involve any personal data and the respondent was well aware that they can opt-out anytime during the data collection phase, any written institutional review board statement is not required.

Data Availability Statement: The associated dataset of the study is available upon request to the corresponding author.

Acknowledgments: We are grateful to the anonymous reviewers and academic editors for helpful comments on the manuscript. We also thank project collaboration between The Standardization of Sustainable Forest Management (Indonesia Ministry of Environment and Forestry) and World Agroforestry (ICRAF). We thank Dani Pamungkas, Marthen Tualaka, and Melky for their assistance in collecting data in the field.

Conflicts of Interest: The authors declare no conflict of interest.

\section{References}

Agustarini, Retno, Yetti Heryati, and Yelin Adalina. 2021. The Effort to Cultivate Natural Dyes (Indigofera Sp.) in Timor Region, NTT. In IOP Conference Series: Earth and Environmental Science, Paper Presented at 2nd International Conference Earth Science and Energy, Kuala Lumpur, Malaysia, 11 November 2020. Bristol: IOP Publishing Ltd., vol. 819. [CrossRef]

Akter, Sonia, Pieter Rutsaert, Joyce Luis, Nyo Me Htwe, Su Su San, Budi Raharjo, and Arlyna Pustika. 2017. Women's Empowerment and Gender Equity in Agriculture: A Different Perspective from Southeast Asia. Food Policy 69: 270-79. [CrossRef]

Ali, Ernest Baba, Ephraim Bonah Agyekum, and Parise Adadi. 2021. Agriculture for Sustainable Development: A SWOT-AHP Assessment of Ghana's Planting for Food and Jobs Initiative. Sustainability 13: 628. [CrossRef]

Amaral, Maria Lopes, and Tenun Ikat. 2019. Millennial Generation Purchasing Behavior in Kupang: Tenun Ikat NTT. Jurnal Ilmu Managemen Dan Ekonomi 11: 57-64.

Andrianyta, Harmi, and Hari Hermawan. 2017. Analisis Perubahan Perilaku Petani Sebagai Adaptasi Terhadap Dampak Perubahan Iklim Di Daerah Iklim Kering Nusa Tenggara Timur. In Prosiding Seminar Nasional Agroinovasi Spesifik Lokasi Untuk Ketahanan Pangan Pada Era Masyarakat Ekonomi ASEAN. Jakarta: Kementerian Pertanian, pp. 571-84.

Angelini, Luciana, Luisa Pistelli, Paola Belloni, Alessandra Bertoli, and Stefano Panconesi. 1997. Rubia Tinctorum a Source of Natural Dyes: Agronomic Evaluation, Quantitative Analysis of Alizarin and Industrial Assays. Industrial Crops and Products 6: 303-11. [CrossRef]

Arifin, Zainal, and Chendy Tafakresnanto. 2019. Pengelolaan Pola Tanam Berbasis Kedelai Dan Jagung Di Lahan Kering. Buletin Palawija 17: 83-93. [CrossRef]

Ariyanti, Mira, and Yenni Asbur. 2018. Tanaman Tarum (Indigofera Tinctoria Linn.) Sebagai Penghasil Zat Pewarna. Jurnal Hutan Pulau-Pulau Kecil 2: 109-22. [CrossRef]

Azam-Ali, Sayed N., and Geoffrey R. Squire. 2002. Principles of Tropical Agronomy. New York: CABI Publishing.

Beneditus Dalupe. 2020. Dari Hutan Ke Politik Studi Terhadap Ekofeminisme Aleta Baun Di Mollo-NTT. Jurnal Polinter 2: 12-32.

Bessie, Juita Lubrina Domina, Anderias Siwa Wunu Langga, and Deitje Naomi Sunbanu. 2021. Analysis of Marketing Strategies in Dealing with Business Competition (Study on Ruba Muri Ikat Weaving MSME in Kupang City). Paper presented at the 2nd International Conference on Tourism and Entreprenenurship 2020, Bali, Indonesia, December 11-12. 
Bobojonov, Ihtiyor, John Lamers, Nodir Djanibekov, Begdullaeva Tamara Ibragimov Nazirbay, Abdu-Kadir Ergashev, Kirsten Kienzler, Rakhimov Azad Ruzumbay Eshchanov, Ruzimov Jumanazar, and Martius Christopher. 2012. Crop Diversification in Support of Sustainable Agriculture in Khorezm. In Cotton, Water, Salts and Soums: Economic and Ecological Restructuring in Khorezm, Uzbekistan. Dordrecht: Springer, pp. 219-33. [CrossRef]

Bogidarwanti, Rina, and Darwo. 2016. Pengaruh Variasi Media Sapih Terhadap Pertumbuhan Dan Kualitas Bibit Cabutan Alnus Nepalensis. In Prosiding Seminar Nasional Masyarakat Biodiversitas Indonesia. Surakarta: Masyarakat Biodiversitas Indonesia, vol. 2, pp. 263-66. [CrossRef]

BPS Provinsi NTT. 2021. Provinsi Nusa Tenggara Timur Dalam Angka 2021. Kupang: BPS Provinsi NTT.

Brockhaus, Maria, Krystof Obidzinski, Ahmad Dermawan, Yves Laumonier, and Cecilia Luttrell. 2012. An Overview of Forest and Land Allocation Policies in Indonesia: Is the Current Framework Sufficient to Meet the Needs of REDD+? Forest Policy and Economics 18: 30-37. [CrossRef]

Buni, Novi Laka, Budi Prihatminingtyas, and Indra Gunawan. 2021. Tangga Di Kabupaten Sumba Barat Contribution of Women's Income Tenun Ikat Weaving and Pig Raising on Household Income in West Sumba Regency. Agridevina 10: 120-31.

Campos, Janaina Karin de Lima, Tiago Ferreira da Silva Araújo, Thaíse Gabriele da Silva Brito, Ana Paula Bezzera da Silva, Rebeca Xavier da Cunha, Mônica Barroso Martins, Nicácio Henrique da Silva, Bianka Santana dos Santos, César Augusto da Silva, and Vera Lucia de Menezes Lima. 2018. Indigofera Suffruticosa Mill. (Anil): Plant Profile, Phytochemistry, and Pharmacology Review. Advances in Pharmacological Sciences 2018: 8168526. [CrossRef]

Chisamya, Grace, Joan DeJaeghere, Nancy Kendall, and Marufa Aziz Khan. 2012. Gender and Education for All: Progress and Problems in Achieving Gender Equity. International Journal of Educational Development 32: 743-55. [CrossRef]

Dahles, Heidi, Titi Susilowati Prabawa, and Juliette Koning. 2020. Local Tourism Businesses in Indonesia: A Pathway to Crisis-Resilient Development? Austrian Journal of South-East Asian Studies 13: 17-33. [CrossRef]

David, Fred, Forest David, and Meredith David. 2019. Strategic Management: Concepts and Cases-A Competitive Advantage Approach, 16th ed. Edited by Fred R. David. South Carolina: Prentice Hall.

Dioh, Septia Sakalini. 2020. Pengaruh Kualitas Produk Dan Harga Terhadap Keputusan Pembelian Souvenir Tenun IIkat NTT : Studi Kasus Di Toko Ina Ndao 2 TDM Kupang. Jurnal Bisnis \& Manajemen 5: 46-53.

Elsahida, Kartika, Ahnas Mifta Fauzi, Illah Sailah, and Iskandar Zulkarnaen Siregar. 2019. Sustainability of the Use of Natural Dyes in the Textile Industry. In IOP Conference Series: Earth and Environmental Science, Paper Presented at The 1st International Seminar on Natural Resources and Environmental Management 2019, IPB International Convention Center (IICC), Bogor, Indonesia, 15 August 2019. Bristol: IOP Publishing Ltd., vol. 399. [CrossRef]

Elvida, Maria Nona. 2015. Pembuatan Kain Tenun Ikat Maumere Di Desa Wololora Kecamatan Lela Kabupaten Sikka Propinsi Nusa Tenggara Timur. Jurnal Holistik 8: 1-22. Available online: http:/ / ejournal.unsrat.ac.id/index.php/holistik/article/view/9997 (accessed on 4 August 2021).

Food and Agriculture Organization of the United Nations. 2003. Digital Soil Map of the World and Derived Soil Properties. Available online: https: / / storage.googleapis.com/fao-maps-catalog-data/uuid/446ed430-8383-11db-b9b2-000d939bc5d8/resources / DSMW.zip (accessed on 4 August 2021).

Fredrick, Charity, Uzoma Darlington Chima, and Udori Noah. 2020. Germination and Early Seedling Growth of Tetrapleura Tetraptera (Schum and Thonn) Taubert under Different Light Insities. Internaional Journal of Agriculture and Rural Development 23: 4767-73.

Frey, Henry Christopher, and Sumeet R. Patil. 2002. Identification and review of sensitivity analysis methods. Risk Analysis 22: 553-78. [CrossRef]

Garrity, Dennis, Roberto Bantilan, Crecencia Bantillan, Pye Tin, and Riaz Mann. 1994. Indigofera Tinctoria: Farmer-Proven Green Manure for Rainfed Ricelands. In Green Manure Production Systems for Asian Ricelands. Edited by Jagdish Kumar Ladha and Garrity Dennis. Los Baños: International Rice Research Institute.

Gerometta, Elise, Isabelle Grondin, Jacqueline Smadja, Michel Frederich, and Anne Gauvin-Bialecki. 2020. A Review of Traditional Uses, Phytochemistry and Pharmacology of the Genus Indigofera. Journal of Ethnopharmacology 253: 112608. [CrossRef]

Głowacki, Eric Daniel, Gundula Voss, Lucia Leonat, Mihai Irimia-Vladu, Siegfried Bauer, and Niyazi Serdar Sariciftci. 2012. Indigo and Tyrian Purple-From Ancient Natural Dyes to Modern Organic Semiconductors. Israel Journal of Chemistry 52: 540-51. [CrossRef]

Görener, Ali, Kerem Toker, and Korkmaz Uluçay. 2012. Application of Combined SWOT and AHP: A Case Study for a Manufacturing Firm. Procedia-Social and Behavioral Sciences 58: 1525-34. [CrossRef]

Gruda, Nazim. 2005. Impact of Environmental Factors on Product Quality of Greenhouse Vegetables for Fresh Consumption. Critical Reviews in Plant Sciences 24: 227-47. [CrossRef]

Haji, Aminoddin. 2010. Functional Dyeing of Wood with Natural Dye Extracted from Berberis Vulgaris Wood Nad Rumex Hymenosepolus Root as Biomordant. Iranian Journal of Chemistry and Chemical Engineering 29: 55-60.

Hartono. 2010. Inventarisasi Aspek—Aspek Tradisi Tenun Ikat Ende. Edited by Yan Yan Sunarya. Jakarta: Direktorat Tradisi, Direktorat Jenderal Nilai Budaya, Seni dan Film, Kementerian Kebudayaan dan Pariwisata.

Heyne. 1987. Tumbuhan Berguna Indonesia III, 3rd ed. Jakarta: Yayasan Sarana Wana Jaya.

Hill, Terry, and Roy Westbrook. 1997. SWOT Analysis: It's Time for a Product Recall. Long Range Planning 30: 46-52. [CrossRef]

Indraningsih, Anastasia Wheni, and Cici Darsih. 2013. Natural Dyes from Plants Extract and Its Applications in Indonesian Textile Small Medium Scale Enterprise. Eksergi 11: 16-22. [CrossRef]

Johnson, Gerry, Kevan Scholes, and Robert W. Sexty. 1989. Exploring Strategic Management. PrenticeHall: Scarborough. 
Kazemi, Fatemeh, Leili Abolhassani, Elahe Azam Rahmati, and Pegah Sayyad-Amin. 2018. Strategic Planning for Cultivation of Fruit Trees and Shrubs in Urban Landscapes Using the SWOT Method: A Case Study for the City of Mashhad, Iran. Land Use Policy 70: 1-9. [CrossRef]

Kieft, Johan, and Damayanti Soekarjo. 2007. Food and Nutritional Security Assessment March 2007: Initial Impact Analysis of the 2006/2007 Crop Season in Comparison to 1997/1998 and 2002/2003 El Nino Events for the Eastern NTT Region. Jakarta: CARE International Indonesia. Available online: https://www.academia.edu/17181902/Food_and_nutritional_security_assessment_March_2007 _Initial_impact_analysis_of_the_2006_2007_crop_season_in_comparison_to_1997_1998_and_2002_2003_El_Nino_events_for_ the_Eastern_NTT_region (accessed on 28 September 2021).

Kota, Paulus Raja, and Wahyu Adiningtyas. 2010. Bertahan Di Tengah Anomali Iklim: Upaya Pemenuhan Pangan Pada Petani Lahan Kering Dan Nelayan Artisanal Di Kupang Menghadapi Perubahan Iklim. Kupang: PIKUL Society.

Kumar, Tarun, and Dal Chand Jhariya. 2015. Land Quality Index Assessment for Agricultural Purpose Using Multi-Criteria Decision Analysis (MCDA). Geocarto International 30: 822-41. [CrossRef]

Kumar, KS Kavi, and Jyoti Parikh. 2001. Indian Agriculture and Climate Sensitivity. Global Environmental Change 11: 147-54. [CrossRef]

Kurniawan, Akhid. 2020. Pra Rancangan Pabrik Zat Warna Alam. Yogyakarta: Universitas Islam Indonesia.

Kwong, Miranda, and Per Ronnås. 2011. Employment Diagnostic Analysis: Nusa Tenggara Timur, Indonesia. Geneva: International Labor Office.

Lake, Smaracdus Consulatus Vivendus, Ricky Avenzora, and Harnios Arief. 2018. Khazanah Kearifan Lokal Dalam Memperkuat Konservasi Dan Ekowisata: Studi Kasus Masyarakat Adat Dawan Di Kabupaten Timor Tengah Utara. Media Konservasi 22: 213-19.

Ledoh, Delfi Yulianti, Alan Charis Sabuna, and Yanti Daud. 2021. Pemanfaatan Tumbuhan Dalam Proses Pewarnaan Kain Tenun Ikat Di Pulau Ndao, Desa Ndao Nuse, Kabupaten Rote Ndao. Indigenous Biologi: Jurnal Pendidikan Dan Sains Biologi 4: 37-45. [CrossRef]

Li, Jingang, Zhongyi Qu, Jin Chen, Bo Yang, and Yongping Huang. 2019. Effect of Planting Density on the Growth and Yield of Sunflower under Mulched Drip Irrigation. Water 11: 752. [CrossRef]

Liu, Yu. 2013. Empirical Study of E-Logistics System Based on Tibet Logistics Industry. Asian Agricultural Research 5: 5-9.

Luik, Serlien, Jacob Matheous Ratu, and Agus Setyobudi. 2021. The Effect of Workplace Stretching Exercise on Reducing Musculoskeletal Complaints in Ndao Ikat Weaving Workers in Rote Ndao District. Lontar: Journal of Community Health 3: 133-40. Available online: https:/ / ejurnal.undana.ac.id/index.php/LJCH/article/view/4453 (accessed on 28 August 2021).

Luna, Tara, Wilkinson Kim, and Dumroese Kasten. 2009. Seed Germination and Sowing Options [Chapter 8]. In Nursery Manual For Native Plants: A Guide For Tribal Nurseries_Volume 1: Nursery Management. Edited by Dumroese Kasten, Tara Luna and Thomas Landis. Washington: U.S. Department of Agriculture, Forest Service, pp. 132-51.

Malley, Zacharia J. U., Johnson Semoka, Josephat Kamasho, and Catherine Kabungo. 2006. Participatory Assessment of Soil Degradation in the Uplands of Southwestern Tanzania: Implications for Sustainable Agriculture and Rural Livelihoods. International Journal of Sustainable Development and World Ecology 13: 183-97. [CrossRef]

Mann, Rauf Ahmad, and Dennis Garrity. 1994. Green Manures in Rice-Wheat Cropping Systems in Asia. In Green Manure Production Systems for Asian Ricelands. Edited by Jagdish Kumar Ladha and Garrity Dennis. Los Baños: International Rice Research Institute.

Marquiafável, Flávia Silva, Maria Dolores Seabra Ferreira, and Simone de Pádua Teixeira. 2009. Novel Reports of Glands in Neotropical Species of Indigofera L. (Leguminosae, Papilionoideae). Flora: Morphology, Distribution, Functional Ecology of Plants 204: 189-97. [CrossRef]

Mighty, Mario. 2015. Site Suitability and the Analytic Hierarchy Process: How GIS Analysis Can Improve the Competitive Advantage of the Jamaican Coffee Industry. Applied Geography 58: 84-93. [CrossRef]

Ministry of Environment and Forestry. 2013. Directorate Genderal of Watershed Management and Social Forestry Regulation no. P. 4/v-set/2013 Critical Land Spatial Analysis Technical Guidance. Available online: http:/ /www.environment.go.ke/ (accessed on 4 August 2021).

Ministry of Environment and Forestry. 2018. The States of Indonesia's Forest 2018; Jakarta: Ministry of Environment and Forestry, Indonesia.

Motsa, Mlamuli Machawe, Martha M. Slabbert, Wim Van Averbeke, and Liesl Morey. 2015. Effect of Light and Temperature on Seed Germination of Selected African Leafy Vegetables. South African Journal of Botany 99: 29-35. [CrossRef]

Muda, Maria Agustina, and Suwito Suwito. 2019. Pengaruh Objek Wisata Danau Kelimutu Dan Tenun Ikat Terhadap Kondisi Ekonomi Masyarakat. JPIG (Jurnal Pendidikan Dan Ilmu Geografi) 3: 299-306. [CrossRef]

Murniati, and Mariana Takandjandji. 2015. Tingkat Pemanfaatan Tumbuhan Penghasil Warna Pada Usaha Tenun Ikat Di Kabupaten Sumba Timur. Jurnal Penelitian Hutan Tanaman 12: 223-37. [CrossRef]

Muzzazinah. 2016. Ethnobotany of Indigofera in Indonesia. Bioedukasi: Jurnal Pendidikan Biologi 9: 7. [CrossRef]

Muzzazinah. 2019. Sumber Pewarna Alami Indigo, Pemetaan Dan Potensi Konservasi Dalam Mempertahankan Plasma Nutfah Tanaman Indigofera Di Indonesia. Proceeding Biology Education Conference: Biology, Science, Enviromental, and Learning Volume 16, Number 1 November 2019. pp. 29-41. Available online: https://jurnal.uns.ac.id/prosbi/article/view/37823 (accessed on 4 August 2021).

Muzzazinah, Tatik Chikmawati, Nunik Sri Ariyanti, Murni Ramli, and Nurmiyati. 2018. Morphological Characterization of Dye Producing Tom Java (Indigofera Tinctoria, L.) in Three Islands of Indonesia. Malaysian Applied Biology 47: 91-99.

Muzzazinah, Kristiandi, Nurmiyati, and Alanindra Saputra. 2021. Introduksi Spesies Baru Indigofera Longeracemosa Boiv. Ex Baill. Di Puspita Batik Guna Meningkatkan Kualitas Bubuk Pewarna Alami Indigo Melalui Teknologi Convective Drying. Proceeding Biology Education Conference: Biology, Science, Environmental, and Learning 18: 130-39. 
Naughton, Colleen, Peter Lovett, and James R. Mihelcic. 2015. Land Suitability Modeling of Shea (Vitellaria Paradoxa) Distribution across Sub-Saharan Africa. Applied Geography 58: 217-27. [CrossRef]

Nezomba, Hatirarami, Tonny Phirilani Tauro, Florence Mtambanengwe, and Paul Mapfumo. 2008. Nitrogen Fixation and Biomass Productivity of Indigenous Legumes for Fertility Restoration of Abandoned Soils in Smallholder Farming Systems, South Africa. Journal of Plant and Soil 25: 161-71. [CrossRef]

Nomleni, Fransina Thresiana, Alan Charis Sabuna, and Since D. Sanam. 2019. Tumbuhan Pewarna Alami Kain Tenun Ikat Suku Meto Di Kecamatan Nunkolo, Kabupaten Timor Tengah Selatan. Indigenous Biologi : Jurnal Pendidikan Dan Sains Biologi 2: 34-41. [CrossRef]

Nugroho, Prasetyo, and Shinya Numata. 2020. Resident Support of Community-Based Tourism Development: Evidence from Gunung Ciremai National Park, Indonesia. Journal of Sustainable Tourism 29: 1-16. [CrossRef]

Nurmalina, Rita, Tintin Sarianti, and Arif Karyadi. 2018. Studi Kelayakan Bisnis. Bogor: PT Penerbit IPB Press.

Nyakpa, Yusuf Muhammad, Ashar Muda Lubis, Mamat Anawar Pulung, Ghaffar Amrah, Ali Munawar, Go Ban Hong, and Nurhajati Hakim. 2008. Kesuburan Tanah. Lampung: Universitas Lampung.

Onyekwelu, Jonathan, Bernd Stimm, Reinhard Mosandl, and Johnson Adeyinka Olusola. 2012. Effects of Light Intensities on Seed Germination and Early Growth of Chrysophyllum Albidum and Irvingia Gabonensis Seedlings. Nigerian Journal of Forestry 42: $58-67$.

Orpa, Anwar Umar, Gusmiaty, and Retno Prayudyaningsih. 2019. Respon pertumbuhan semai sengon buto (Enterolobium cyclocarpum) dengan aplikasi pot media semai berbahan dasar sampah organik. Jurnal Eboni 1: 1-20.

Ponmari, Guruvaiah, Arunachalam Annamalai, Velliyur Kanniappan Gopalakrishnan, PTV Lakshmi, and Chandrasekharan Guruvayoorappan. 2014. NF-KB Activation and Proinflammatory Cytokines Mediated Protective Effect of Indigofera Caerulea Roxb. on CCl4 Induced Liver Damage in Rats. International Immunopharmacology 23: 672-80. [CrossRef]

Prabhu, K. H., and Aniket S. Bhute. 2015. Plant Based Dyes and Mordant: A Review. Journal of Natural Products and Plant Resources 2: 649-64.

Prakash, Dhan, Samiksha Suri, Garima Upadhyay, and Brahma N. Singh. 2007. Total Phenol, Antioxidant and Free Radical Scavenging Activities of Some Medicinal Plants. International Journal of Food Sciences and Nutrition 58: 18-28. [CrossRef] [PubMed]

Pujiono, Eko, Ronggo Sadono, and Muhamad Ali Imron. 2019. Assessment of causes and future deforestation in the mountainous tropical forest of Timor Island, Indonesia. Journal of Mountain Science 16: 2215-31.

Rai, Neetij, and Bikash Thapa. 2015. A Study on Purposive Sampling Method in Research. Kathmandu: Kathmandu School of Law. Available online: http:/ / www.academia.edu/28087388 (accessed on 4 August 2021).

Rauch, Peter. 2007. SWOT Analyses and SWOT Strategy Formulation for Forest Owner Cooperations in Austria. European Journal of Forest Research 126: 413-20. [CrossRef]

Renukadevi, K. P., and S. Suhani Sultana. 2011. Determination of Antibacterial, Antioxidant and Cytotoxicity Effect of Indigofera Tinctoria on Lung Cancer Cell Line NCI-H69. International Journal of Pharmacology 7: 356-62. [CrossRef]

Richards, Greg. 2018. Cultural Tourism: A Review of Recent Research and Trends. Journal of Hospitality and Tourism Management 36: 12-21. [CrossRef]

Rivai, Reza Ramadan, FIitri Fatma Wardani, and Micha Gracanna Devi. 2015. Germination and Breaking Seed Dormancy of Alpinia Malaccensis. Nusantara Bioscience 7: 67-72. [CrossRef]

Riyanto, Edy. 2018. Penentuan Tingkat Diskonto Dalam Penilaian Hutan. Jurnal Pajak Indonesia 2: 39-48. [CrossRef]

Saarinen, Jarkko. 2018. Beyond Growth Thinking: The Need to Revisit Sustainable Development in Tourism. Tourism Geographies 20: 337-40. [CrossRef]

Saaty, Thomas L. 2008. Competitive Priorities and Knowledge Management: An Empirical Investigation of Manufacturing Companies in UAE. International Journal Services Sciences 1: 83-98. [CrossRef]

Sabuna, Alan Charis, and Fransina Thresiana Nomleni. 2020. Identification of Plants Natural Dye by Meto Tribe in South Central Timor. In IOP Conference Series: Materials Science and Engineering, Paper presented at International Seminar on Chemical Engineering Soehadi Reksowardojo (STKSR) 2019, Kupang, Indonesia, 7-9 October 2019. Bristol: IOP Publishing Ltd., vol. 823. [CrossRef]

Sagredo, Esteban A., Summer Rupper, and Thomas V. Lowell. 2014. Sensitivities of the Equilibrium Line Altitude to Temperature and Precipitation Changes along the Andes. Quaternary Research 81: 355-66. [CrossRef]

Salma, Irfa Ina Rohana, Dana Kurnia Syabana, Yudi Satria, and Roberts Cristianto. 2018. Diversifikasi Produk Tenun Ikat Nusa Tenggara Timur Dengan Paduan Teknik Tenun Dan Teknik Batik. Dinamika Kerajinan Dan Batik 35: 85-94. [CrossRef]

Samadara, Selfesina. 2018. Pemberdayaan Perempuan Pengrajin Tenun Ikat Di Kampung Prai Ijing, Desa Tebar, Kecamatan Kota, Kabupaten Sumba Barat, Nusa Tenggara Timur Untuk Meningkatkan Perekonomian Keluarga Dan Mendukung Pengembangan Pariwisata Daerah. Jurnal Akuntasi, Keuangan Dan Audit 3: 44-53. [CrossRef]

Santos, Irailton Prazeres dos, Luís Cláudio Nascimento da Silva, Márcia Vanusa da Silva, Janete Magali de Araújo, Marilene da Silva Cavalcanti, and Vera Lucia de Menezes Lima. 2015. Antibacterial Activity of Endophytic Fungi from Leaves of Indigofera Suffruticosa Miller (Fabaceae). Frontiers in Microbiology 6: 350. [CrossRef] [PubMed]

Santos, Paulo Henrique Dos, Sandra Miranda Neves, Daniele Ornaghi Sant'Anna, Carlos Henrique de Oliveira, and Henrique Duarte Carvalho. 2019. The Analytic Hierarchy Process Supporting Decision Making for Sustainable Development: An Overview of Applications. Journal of Cleaner Production 212: 119-38. [CrossRef] 
Saragih, Bungaran. 2007. Integrated Rural Development Based on Agribusiness in East Nusa Tenggara. In Proceedings of a Workshop to Identify Sustainable Rural Livelihoods; Edited by Michael Blyth, I. E. T. Salean, Siliwoloe Djoeroemana, Bronwyn Myers and Jeremy Russell-Smith. Canberra: ACIAR, pp. 32-35. Available online: http://aciar.gov.au/files/node/3367/pr126_pdf_78826.pdf (accessed on 4 July 2021).

Scheyvens, Regina, and Emma Hughes. 2019. Can Tourism Help to 'End Poverty in All Its Forms Everywhere'? The Challenge of Tourism Addressing SDG1. Journal of Sustainable Tourism 27: 1061-79. [CrossRef]

Schrire, Brian. 2013. A Review of Tribe Indigofereae (Leguminosae-Papilionoideae) in Southern Africa (Including South Africa, Lesotho, Swaziland \& Namibia; Excluding Botswana). South African Journal of Botany 89: 281-83. [CrossRef]

Séquin-Prey, Margareta. 1981. The Chemistry of Plant and Animal Dyes. Journal of Chemical Education 58: 301-5. [CrossRef]

Seran, Wilhelmina, and Yanete Wori Hana. 2018. Identifikasi Jenis Tanaman Pewarna Tenun Ikat Di Desa Kaliuda Kecamatan Pahunga Lodu Kabupaten Sumba Timur. Agrikan: Jurnal Agribisnis Perikanan 11: 1. [CrossRef]

Setiawan, Budiana, and Raden Roro Nur Suwarningdyah. 2014. Strategy for Development of Kupang Ikat Woven, East Nusa Tenggara Province. Pendidikan Dan Kebudayaan 20: 353-67. Available online: https://media.neliti.com/media/publications/124320-nonea4544e93.pdf (accessed on 28 September 2021). [CrossRef]

Setiono, and Azwarta. 2020. Pengaruh Pemberian Pupuk Kandang Sapi Terhadap Pertumbuhan Dan Hasil Tanaman Jagung Manis (Zea Mays L). Jurnal Sains Agro 5. Available online: https:/ / ojs.umb-bungo.ac.id/index.php/saingro/article/view/463 (accessed on 4 August 2021). [CrossRef]

Sharpley, Richard. 2020. Tourism, Sustainable Development and the Theoretical Divide: 20 Years On. Journal of Sustainable Tourism 28: 1932-46. [CrossRef]

Shopee. n.d. Indigo Pasta Daun Indigofera Pewarna Alam_Shopee Indonesia. Available online: https://shopee.co.id/Indigo-Pasta-DaunIndigofera-Pewarna-Alam-i.21890088.2000093842?sp_atk=6eec2a37-753a-483c-98cf-6caa20f07c6e (accessed on 4 August 2021).

Shrestha, Raunak, Janaki Alavalapati, and Robert Steven Kalmbacher. 2004. Exploring the Potential for Silvopasture Adoption in South-Central Florida: An Application of SWOT-AHP Method. Agricultural Systems 81: 185-99. [CrossRef]

Siombo, Marhaeni Ria. 2019. Kearifan Lokal Dalam Proses Pembuatan Tenun Ikat Timor (Studi Pada Kelompok Penenun Di Atambua-Ntt). Bina Hukum Lingkungan 4: 97. [CrossRef]

Su, Yanfang, Min Lü, Fengying Yang, Chunzheng Li, Lizhi Di, Di Wu, Zengjun Guo, Juxian Lü, and Dean Guo. 2008. Six New Glucose Esters of 3-Nitropropanoic Acid from Indigofera Kirilowii. Fitoterapia 79: 451-55. [CrossRef] [PubMed]

Sulaiman, Hesti, and Anita. 2020. Peran Kaum Perempuan Dalam Meningkatkan Sosial Ekonomi Keluarga Melalui Kearifan Lokal Tenun Ikat Di Desa Nggorea. Socia : Jurnal Ilmu-Ilmu Sosial 17: 11-20. Available online: https://scholar.archive.org/work/3o7 ezlyzpzcxzegnli3an3uuky/access/wayback/https://journal.uny.ac.id/index.php/sosia/article/download/32564/pdf (accessed on 28 September 2021). [CrossRef]

Sulayman, Christina Mery, Hartono Karnadi, and Luri Renaningtyas. 2017. Perancangan Karya Fotografi Fashion Kain Tenun Insana Dari Pulau Timor Nusa Tenggara Timur. Jurnal DKV Adiwarna 1: 10.

Suriadi, Ahmad, Anny Mulyani, Lia Hadiawati, and Suratman. 2021. Biophysical Characteristics of Dry-Climate Upland and Agriculture Development Challenges in West Nusa Tenggara and East Nusa Tenggara Provinces. In IOP Conference Series: Earth and Environmental Science, Paper Presented at 1st International Conference on Sustainable Tropical Land Management, Bogor, Indonesia, 16-18 September 2020. Bristol: IOP Publishing Ltd., vol. 648, p. 012014. [CrossRef]

Susanti, Santi. 2021. Peluang Dan Tantangan Bisnis Kriya Saat Pandemi Covid-19. Jurnal Pengabdian Pada Masyarakat 6: 2021. Available online: http:/ / ppm.ejournal.id/index.php/pengabdian/article/view/778 (accessed on 28 September 2021).

Susilawati, Dewa Ayu Putu. 2010. Peranan Museum Nusa Tenggara Timur Dalam Pembelajaran Dan Pelestarian Tenun. Jakarta: Universitas Indonesia.

Tas'au, Petrus Richardus. 2016. Pelestarian Budaya Tenun Buna Dalam Mengembangkan Ekonomi Kerakyatan (Studi Etnografi Masyarakat Adat Sonaf Maubes). Paper presented at the National Conference On Economic Education 2016, Malang, Indonesia, August 27.

Tiwa, Ferna. 2016. Evaluasi Kelayakan Proyek Berdasarkan Analisis Kriteria Investasi. Jurnal Sipil Statik 4: 577-83.

UNWTO and UNDP. 2017. Tourism and the Sustainable Development Goals-Journey to 2030. Edited by UN World Tourism Organisation. Madrd: UNWTO. [CrossRef]

Veloso, Aniele C. R., Priscila S. Silva, Walisson K. Siqueira, Karen L. R. Duarte, Ingrid L. V. Gomes, Henrique T. Santos, and Marcilio Fagundes. 2017. Intraspecific Variation in Seed Size and Light Intensity Affect Seed Germination and Initial Seedling Growth of a Tropical Shrub. Acta Botanica Brasilica 31: 736-41. [CrossRef]

Vieira, Jeymesson Raphael Cardoso, Ivone Antônia De Souza, Silene Carneiro Do Nascimento, and Sônia Pereira Leite. 2007. Indigofera Suffruticosa: An Alternative Anticancer Therapy. Evidence-Based Complementary and Alternative Medicine 4: 355-59. [CrossRef]

Wang, ChengYong. 2010. Tows Matrix Analysis on Developing Urban Agriculture in the Pearl River Delta Area. Asian Agricultural Research 2: 21-24.

Wangge, Vinsensius. 2021. Nilai-Nilai Moral Tradisional Masyarakat Lio Selatan Dalam Ragam Budaya Tenun Ikat:(Studi Kasus Pada Masyarakat Mbuli Kabupaten Ende). Jurnal Konsepsi 10: 145-54. Available online: https://p3i.my.id/index.php/konsepsi/ article/view/69\%0Ahttps:/ / p3i.my.id/index.php/konsepsi/article/download/69/66 (accessed on 4 August 2021).

Westoby, Ross, Sarah Gardiner, Roadney. W. (Bill) Carter, and Noel Scott. 2021. Sustainable Livelihoods from Tourism in the '10 New Balis' in Indonesia. Asia Pacific Journal of Tourism Research 26: 702-16. [CrossRef] 
White, Thomas H., Yara de Melo Barros, Pedro F. Develey, Iván C. Llerandi-Román, Omar A. Monsegur-Rivera, and Ana M. TrujilloPinto. 2015. Improving Reintroduction Planning and Implementation through Quantitative SWOT Analysis. Journal for Nature Conservation 28: 149-59. [CrossRef]

Widiatmaka. 2016. Integrated Use of GIS, AHP and Remote Sensing in Land Use Planning for Tropical High Altitude Vegetable Crops. Journal of Applied Horticulture 18: 87-99. [CrossRef]

Windiyarti, Dara. 2006. Tradisi, Agama, Dais Modertosasi Dalam Perkembangan Budaya Timor. Sabda: Jurnal Kajian Kebudayaan 1: 36-43. [CrossRef]

Wiryanta, Bernardinus T. Wahyu. 2007. Media Tanam Untuk Tanaman Hias. Jakarta: AgroMedia. 